\title{
Modelling green macroalgal blooms on the coasts of Brittany, France to enhance water quality management
}

\author{
Thierry Perrot ${ }^{a, *}$, Nadège Rossi $^{a}$, Alain Ménesguen $^{\mathrm{b}}$, Franck Dumas $^{\mathrm{b}}$ \\ ${ }^{a}$ Centre d'Etude et de Valorisation des Algues (CEVA), Presqu'île de Pen Lan BP3, 22610 Pleubian, France \\ ${ }^{\mathrm{b}}$ Institut Français de Recherche pour l'Exploitation de la Mer (IFREMER), BP 70, 20280 Plouzané, France \\ *: Corresponding author : Thierry Perrot, tel.: + 33296229350 ; fax: + 33296228438 ; email address : \\ thierry.perrot@ceva.fr
}

\begin{abstract}
:
First recorded in the 1970s, massive green macroalgal blooms have since become an annual recurrence in Brittany, France. Eutrophication (in particular to anthropogenic nitrogen input) has been identified as the main factor controlling Ulva 'green tide' events. In this study, we modelled Ulva proliferation using a two-dimensional model by coupling hydrodynamic and biological models (coined 'MARS-Ulves') for five sites along the Brittany coastline (La Fresnaye Bay, Saint-Brieuc Bay, Lannion Bay, Guissény Bay and Douarnenez Bay). Calibration of the biological model was mainly based on the seasonal variation of the maximum nitrogen uptake rate $\left(\mathrm{V}_{\operatorname{maxN}}\right)$ and the half-saturation constant for nitrogen $\left(K_{N}\right)$ to reproduce the internal nutrient quotas measured in situ for each site. In each bay, model predictions were in agreement with observed algal coverage converted into biomass. A numerical tracking method was implemented to identify the contribution of the rivers that empty into the study bays, and scenarios of decreases in nitrate concentration in rivers were simulated. Results from numerical nitrogen tracking highlighted the main nitrogen sources of green tides and also showed that each river contributes locally to green tides. In addition, dynamic modelling showed that the nitrate concentrations in rivers must be limited to between 5 and $15 \mathrm{mg} \mathrm{l}^{-1}$, depending on the bay, to reduce Ulva biomass by half on the coasts. The three-step methodology developed in this study (analysing total dissolved inorganic nitrogen flux from rivers, tracking nitrogen sources in Ulva and developing scenarios for reducing nitrogen) provides qualitative and quantitative guidelines for stakeholders to define specific nitrogen reduction targets for better environmental management of water quality.
\end{abstract}

\section{Highlights}

We model five sites of Brittany coast severely polluted by green tides Use of original parameters to calibrate and validate the model - We examine changes of macroalgal biomass versus nitrate reduction in rivers - The target level in nitrate varies from site to site between $5 \mathrm{mg} \mathrm{l}^{-1}$ and $15 \mathrm{mg} \mathrm{l}^{-1}$ - Every nitrogen source has a local impact on Ulva nitrogen content as well as seawater $>$ Natural open sea is a significant contributor to nitrogen budget in Ulva in spring

Keywords : 2D model ; Ulva ; Eutrophication ; Coastal waters ; Brittany ; Tracers ; Nutrient reductions 


\section{Introduction}

Massive development of opportunistic green macroalgae is a worldwide phenomenon related to coastal water eutrophication (Valiela et al., 1997). In coastal environments, there are different types of green tides. Green tides can occur on mud flats — as reported in Italy (Viaroli et al., 2005), Spain (Hernandez et al., 1997), Denmark (Pedersen and Borum, 1996; Lyngby et al., 1999; Riisgard et al., 2008), the Netherlands (Malta and Verschuure, 1997), the USA (Nelson et al., 2008), Ireland (Jeffrey et al., 1995) and the UK (Scanlan et al., 2007) or on sandy beaches where free floating macroalgae wash up on beaches — as in France (Piriou et al., 1991; Merceron et al., 2007) and in China (Liu et al., 2010). The main consequences of macroalgal blooms include oxygen depletion in calm waters, which causes changes in the zoobenthic community (Norkko and Bonsdorff, 1996), decline in seagrass populations (McGlathery, 2001), and production of hydrogen sulphide (Briand, 1989). In all cases, nutrient enrichment due to anthropogenic activity is the main cause of these macroalgal blooms. Opportunistic macroalgae are therefore one of the quality indicators listed in the European Water Framework Directive (WFD, 2000). Although eutrophication occurs in all aquatic ecosystems, coastal waters are particularly sensitive because they represent the last compartment where all nutrient inputs accumulate from the entire water cycle and run-off waters. For this reason, marine estuaries have the highest nutrient inputs per unit surface area of all aquatic ecosystems (Howarth, 1993). For instance, in Brittany, in 2008, almost 76,000 t of nitrogen was discharged into the sea according to the Loire-Brittany Water Agency. Brittany has the highest positive nitrogen balance in France due to intensive farming activities (Campling et al., 2005). Nutrient enrichment, combined with semi-enclosed areas with poor flushing, shallow depths and particularly clear waters, has made Brittany coasts very sensitive to macroalgal blooms, which are generally composed of drifting Ulva spp. (Dion and Le Bozec, 1996). Macroalgal 'green tides' have been a regular occurrence in Brittany since the 
1970s (Piriou et al., 1991, Merceron et al., 2007) in both coastal and transitional waters and have become a real environmental issue. Since 2002, green macroalgae blooms occurring on Brittany coasts have been monitored (CEVA, 2011). Washed-up and drifting green algae covered almost 1000 ha of sandy beaches or bays in Brittany in June 2009. To avoid negative impacts on tourism and risks for human health related to decomposition gases, green algae are now being collected on numerous beaches. In 2010 , nearly $74,000 \mathrm{~m}^{3}$ of green algae were collected in Brittany (CEVA, 2011). However, removal and disposal of seaweeds are only short-term solutions. These actions must be accompanied by preventive measures, such as upstream reduction in nitrate inputs in aquatic ecosystems. Numerous models have been constructed to determine which factors control macroalgal blooms (Ménesguen and Salomon, 1988; Runca et al., 1996; Solidoro et al., 1997; Brush and Nixon, 2010). For management purposes, these models mainly provide qualitative recommendations and sometimes quantitative guidelines. In Brittany, it is now known that macroalgal blooms occurring in coastal waters are principally due to anthropogenic nitrogen loading (Piriou and Ménesguen, 1990; Ménesguen and Piriou, 1995). Due to the high cost of the preventive actions, catchment area managers need highly reliable prediction tools to set nitrate concentration targets for the main rivers and thus control green tides. However, there are no models to accurately estimate the effects of nitrate load reduction on green tides with regard to water management issues. The MARS-Ulves model is derived from two coupled models: a two-dimensional (2D) version of the hydrodynamic model MARS (Lazure and Dumas, 2008), and an improved version of the biogeochemical model of Ulva production described by Ménesguen et al. (2006). The main goal of the work presented here was to predict nitrate threshold values for the control of green tides, which can vary from bay to bay in Brittany. Numerical nitrogen tracking provided further information on the source of the Ulva nitrogen pool thereby identifying the main contributors of macroalgal blooms. 


\section{Site description}

Study sites were all located on the north coast of Brittany, except the Douarnenez Bay located in south-western Brittany (Figure 1). All sites regularly exchange nutrients with the open sea: the English Channel for La Fresnaye, Saint-Brieuc, Lannion and Guissény Bays, and the Iroise Sea for Douarnenez Bay. The mean tide amplitude ranges from $3.50 \mathrm{~m}$ in Douarnenez Bay to $6.60 \mathrm{~m}$ in La Fresnaye Bay, with intermediate amplitudes in Guissény, Lannion and Saint-Brieuc Bays (4.50, 5.30 and $6.40 \mathrm{~m}$, respectively). These study sites have small residual drift of water masses $\left(<0.05 \mathrm{~m} \mathrm{~s}^{-1}\right)$, resulting in a long water residence times and low dispersion of nutrients and drifting algae. These physical conditions favour massive development of green algae, regularly recorded since 2002 with aerial surveys. Changes in seaweed biomass in each bay generally depend on nitrate fluxes that occur in the spring. Seaweed biomass is also largely influenced by local geological characteristics (nature of the underlying bedrock, i.e. slate or granite), precipitation (Ménesguen and Piriou, 1995) and residual stocks from the previous year, as shown for macroalgae blooms on mud flats (Kamermans et al., 1998). Maximum annual algal cover and foreshore surface areas are presented for each study site in Table 1. Biomass quantities can also be used to compare sites: e.g. in the summer of 1998, biomass totalled $2800 \mathrm{t}$ in La Fresnaye Bay, $8400 \mathrm{t}$ in SaintBrieuc bay, 2400 t in Lannion Bay, 800 t (wet weight; ww) in Guissény Bay and 3400 t in Douarnenez Bay.

\section{Description of the modelling system}

\subsection{Hydrodynamic model}

The purpose of the hydrodynamic model was to determine currents, sea level and to advect/disperse all dissolved and suspended substances from rivers. These variables were then used in the biological model to compute changes in state variables (see $\S 3.2$ ). The 2D 
hydrodynamic model MARS (Lazure and Dumas, 2008) was used, assuming that the horizontal current component does not vary significantly from the surface to the bottom (barotropic approximation) and that thermohaline stratification is negligible. In the five shallow-water bays studied here, there is significant tidal mixing. A 2D model is thus appropriate and also significantly decreases computation time, thereby accommodating a higher number of scenarios of nitrogen load reduction. At open ocean boundaries, the model was forced by sea-surface height, provided by a succession of nested models with decreasing extensions and increasing spatial resolutions, their number depending on the study area (see inset of Figure 2). Heat fluxes throughout the domain were computed according to Luyten and De Mulder (1992). Bathymetric data used for the intermediate and detailed models were extracted from bathymetric charts provided by the French Research Institute for Exploration of the Sea (IFREMER). The global 2D model had a mesh size of about $5 \mathrm{~km}$ and was forced by the Schwiderski atlas (Schwiderski, 1983) which provided eight tidal constituents (M2, S2, $\mathrm{K} 1, \mathrm{O} 1, \mathrm{~N} 2$, P1, K2, Q1). Meteorological data (air temperature, air moisture, atmospheric pressure, cloud cover, solar irradiance) were taken from the French Meteorological Office's global and spectral general circulation model ARPEGE and were used for computing sea temperature and surface wind-induced stresses. Flow rates and nutrient concentrations of nitrate $\left(\mathrm{NO}_{3}\right)$, ammonium $\left(\mathrm{NH}_{4}\right)$ and dissolved phosphate $\left(\mathrm{PO}_{4}\right)$ of the rivers were supplied by local municipalities. When no high-frequency time-series of nutrient fluxes was available at the downstream limit of a river, linear regression was used to extrapolate between measured data and the nearest gauging station, taking into account the ratio of the catchment areas and a rainfall factor. No in situ concentrations were available along the open boundaries for any of the five studied sites or simulated year; we therefore used results from an ecological model developed by IFREMER for the Brittany coast (Vanhoutte-Brunier et al., 2008). Representative concentrations of $\mathrm{NO}_{3}, \mathrm{NH}_{4}$ and $\mathrm{PO}_{4}$ time-series for the year 2002 were 
extracted from this model at a fixed point located north Saint-Brieuc Bay (see location in Figure 1) and were used for each site whatever the year simulated. These time-series were in good agreement with in situ nutrient concentrations at the Estacade site (data provided by the 'Service d'Observation en Milieu Littoral, INSU-CNRS, Roscoff' - see location in Figure 1) (see Figure 3).Using the same time-series for the five studied sites was appropriate because nutrient concentrations at each site follow the same annual and seasonal patterns. Moreover, for nitrogen load reduction scenarios, the use of a generic offshore value is acceptable for an analysis of the relative importance of offshore versus river contributions.

Figure 4 shows instantaneous nitrate concentrations in Fresnaye, Saint-Brieuc, Lannion, Guissény and Douarnenez Bays resulting from the advection/dispersion of nitrogen coming from rivers and open boundaries. Results were obtained using real tidal and meteorological conditions for each simulated year.

\subsection{Ulva biological model: main processes and state variables}

The biological model was based on the coupling of the hydrodynamic model MARS with the biogeochemical model implemented by Ménesguen et al. (2006). The state variables of the biogeochemical model were represented by nitrate $(X 1)$, ammonium $(X 2)$, phosphate $(X 3)$, detrital organic nitrogen $(X 4)$, detrital organic phosphorus $(X 5)$, the nitrogen pool of Ulva (X6), the phosphorus pool of Ulva (X7) and Ulva biomass (X8). Unlike the original Menesguen et al. (2006) model, no transport mechanism was considered in the model and variables related to $U l v a(X 6, X 7, X 8)$ were therefore considered as fixed variables.

The daily growth rate of Ulva was described as a function of the maximal growth rate $\left(\mu_{\text {max ulva }}\right)$, temperature $\left(\mathrm{f}_{\mathrm{T}}\right)$, light $\left(\mathrm{f}_{\text {Lulva }}\right)$ and nutrient limitation $\left(\mathrm{f}_{\text {Nulva }}, \mathrm{f}_{\text {Pulva }}\right)$ :

$\mu_{\text {ulva }}=\mu_{\text {maxulva }} \times f_{T} \times f_{\text {Lulva }} \times \min \left(f_{\text {Nulva }}, f_{\text {Pulva }}\right) \quad$ with $\quad 0 \leq\left\{f_{T} ; f_{\text {Lulva }} ; f_{\text {Nulva }} ; f_{\text {Pulva }}\right\} \leq 1$ 
The concept of Thornton and Lessen (1978) was adopted to represent the temperature limitation factor (Figure 4). This function uses optimum temperature curves for which the growth rate increases up to an optimum and then decreases at higher temperatures. Linear or exponential increases in growth rate with temperature (e.g. "Q10 $=2$ " law) are not appropriate for green algae because these functions increase indefinitely with temperature and are never limited by maximum sea temperature when the optimum growth temperature is reached.

Using the Thornton and Lessen formulation, the temperature effect was expressed as $\mathrm{f}_{\mathrm{T}}=\mathrm{K}_{\mathrm{a}}(\mathrm{T}) \times \mathrm{K}_{\mathrm{b}}(\mathrm{T})$

with

$$
\begin{aligned}
& K_{a}(T)=\frac{K_{1} \exp ^{\gamma_{1}\left(T-T_{\min }\right)}}{1+K_{1}\left[\exp ^{\gamma_{1}\left(T-T_{\min }\right)}-1\right]} ; K_{b}(T)=\frac{K_{4} \exp ^{\gamma_{2}\left(T_{\max }-T\right)}}{1+K_{4}\left[\exp ^{\gamma_{2}\left(T_{\max }-T\right)}-1\right]} \\
& \gamma_{1}=\frac{1}{T_{o p t \text { min }}-T_{\min }} \ln \left[\frac{K_{2}\left(1-K_{1}\right)}{K_{1}\left(1-K_{2}\right)}\right] ; \gamma_{2}=\frac{1}{\left(T_{\max }-T_{o p t \max }\right)} \ln \left[\frac{K_{3}\left(1-K_{4}\right)}{K_{4}\left(1-K_{3}\right)}\right],
\end{aligned}
$$

where $T$ is the sea temperature; $T_{\text {opt min }}$ and $T_{\text {opt max }}$, minimum and maximum temperature for the optimal interval; $T_{\min }$ and $T_{\max }$, minimum and maximum tolerable temperatures; and $K_{l}$, $K_{2}, K_{3}, K_{4}$, constants controlling the shape of the temperature response curve.

The effect of light on Ulva growth (see inset in Figure 5) was based on a MichaelisMenten equation and depended on the light available at the sea bottom $\left(I_{H}\right)$ and the timevarying optimal light intensity for Ulva $\left(I_{\text {optulva }}\right)$ :

$$
f_{\text {Lulva }}=\frac{I_{H} / 2}{I_{\text {opt }}+I_{H} / 2}
$$

The light available at the sea bottom follows a classical Lambert-Beer function:

$$
I_{H}=I_{\text {surf }} \times \exp \left(-k_{H} \times H\right)
$$


where $\mathrm{I}_{\text {surf }}$ is the solar radiation at the sea surface; $k_{H}$, the light extinction coefficient and $H$, water column height. In Eq. (3), photosynthetically active radiation is approximately half of the total solar flux (Brock, 1981).

The original cell nutrient quota model (Droop, 1968) was adapted for the nutrient limitation factor which is controlled by the internal nitrogen or phosphorus pools $\left(Q_{N}, Q_{P}\right)$ for Ulva:

$$
\begin{aligned}
& f_{\text {Nulva }}=\left(\frac{Q_{N}-Q_{\min N}}{Q_{N}}\right) /\left(\frac{Q_{\operatorname{maxN}}-Q_{\min N}}{Q_{N}}\right) \\
& f_{\text {Pulva }}=\left(\frac{Q_{P}-Q_{\min P}}{Q_{P}}\right) /\left(\frac{Q_{\max P}-Q_{\min P}}{Q_{P}}\right)
\end{aligned}
$$

where $Q_{N}=X 6 / X 8$ and $Q_{P}=X 7 / X 8 ;\left(Q_{\min N} ; Q_{\max N}\right)$ are the minimum and maximum nitrogen cell quotas; $\left(Q_{\min P} ; Q_{\max P}\right)$, the minimum and maximum phosphorus cell quotas. The introduction of minimum and maximum cell nitrogen and phosphorus quotas is useful for normalising the nutrient limitation effect between 0 and 1 :

$$
f_{\text {Nulva }}= \begin{cases}1 & \text { if } Q_{N}=Q_{\operatorname{maxN}} \\ 0 & \text { if } Q_{N}=Q_{\min N}\end{cases}
$$

and:

$$
f_{\text {Pulva }}=\left\{\begin{array}{l}
1 \text { if } Q_{P}=Q_{\max P} \\
0 \text { if } Q_{P}=Q_{\min P}
\end{array}\right.
$$

The variation in the internal nitrogen and phosphorus pool for Ulva depends on nitrogen $\left(\mathrm{V}_{\text {Nulva }}\right)$ and phosphorus $\left(\mathrm{V}_{\text {Pulva }}\right)$ uptake velocities, which are controlled by the nutrient concentration in seawater and the nitrogen and phosphorus quotas:

$$
\left\{\begin{array}{l}
V_{\text {Nulva }}(t)=V_{\operatorname{maxN}}(t) \times \frac{X 1+X 2}{K_{N}(t)+X 1+X 2} \times \frac{Q_{\operatorname{maxN}}-Q_{N}}{Q_{\operatorname{maxN}}-Q_{\min N}} ; \text { if } I_{\text {suff }}>0 \\
V_{\text {Nulva }}(t)=0 ; \text { else }
\end{array}\right.
$$




$$
\left\{\begin{array}{l}
V_{\text {Pulva }}(t)=V_{\max P}(t) \times \frac{X 3}{K_{P}(t)+X 3} \times \frac{Q_{\max P}-Q_{P}}{Q_{\max P}-Q_{\min P}} ; \text { if } I_{\text {surf }}>0 \\
V_{\text {Pulva }}(t)=0 ; \text { else }
\end{array}\right.
$$

where $V_{\max }(\mathrm{t})$ and $V_{\max P}(\mathrm{t})$ are the imposed time-varying, maximal uptake rates for nitrogen and phosphorus, $K_{N}(\mathrm{t})$ and $K_{P}(\mathrm{t})$, the imposed time-varying, half-saturation constants for nitrogen and phosphorus uptake.

Ulva mortality is another important component in the biomass decrease that generally occurs during July and August in the sites affected by green tides in Brittany. This parameter plays a key role in nutrient recycling by supplying detrital organic matter. It was assumed to be only dependent on temperature for immersed Ulva biomass:

$$
m_{u l v a}=m_{u l v a}^{0} \times f_{T 2} \text { with } f_{T 2}=\exp \left(f_{T 2}^{0} \times T\right)
$$

where $m_{u l v a}^{0}$ represents the mortality rate at the baseline temperature and $f_{T 2}^{0}$, the effect of temperature on the kinetics of mortality, mineralisation and nitrification. For exposed intertidal Ulva biomass, to properly model enhanced degradation caused by desiccation and greater insolation during the ebb tide, the mean emersion time percentage was weighted:

$m_{u l v a}=m_{u l v a}^{0} \times f_{T 2} \times($ emer $/ 100+1)$

where emer represents the mean percentage of emersion time for each computation cell. The map of the mean percentage of emersion time was established using the hydrodynamic model from the whole month of January 1996, which is representative of two natural spring and neap tides. Detrital organic nitrogen (DON) and phosphorus (DOP) from the detritus component are then mineralised via bacterial activity and released back to the water column as dissolved ammonium, which can be nitrified, and phosphorus. Mineralisation and nitrification rates depend on temperature.

For nitrogen and phosphorus mineralisation: 


$$
\begin{aligned}
& k_{\text {rem } N}=k_{\min N}^{0} \times f_{T 2} \\
& k_{\text {rem } P}=k_{\min P}^{0} \times f_{T 2}
\end{aligned}
$$

where $k^{0}{ }_{\min N}$ and $k_{\min P}^{0}$ are the nitrogen and phosphorus mineralisation rates at the baseline temperature.

For nitrification:

$$
k_{\text {nitrif }}=k_{\text {nitrif }}^{0} \times f_{T 2}
$$

where $k_{n i t r i f}^{0}$ is the nitrogen mineralisation rate at the baseline temperature.

Sediment and water column interactions are of significant ecological importance for shallow coastal waters (Reay et al., 1995; Vouvé et al., 2000), particularly in the intertidal zone where growth of free-floating Ulva thalli occurs. During the incoming tide, Ulva thalli that are located just above the bottom layer are kept in suspension by water movement and, due to tidal flushing, are immediately exposed to nitrogen (ammonium and nitrate) and phosphorus from the intertidal sediment. The influence of tidal action on the release of nutrients from intertidal sediments has been described by Cabrita et al. (1998) and Rocha (1998). At the onset of submersion, high quantities of nutrients are exported from the sediment to the water column and tidal flushing decreases monotonically with increasing water depth, typically for 3 to $4 \mathrm{~h}$ (Usui et al., 1998). The depth of oxygen penetration in the sediment (Henriksen et al., 1981), temperature (Vouvé et al., 2000), time of air exposure of the sediment and tidal amplitude (Cabrita et al., 1998) also determine the sediment flux, but these parameters can be considered as secondary with regard to the effect of the tide and agitation induced by wind stress. Ulva remineralisation also provides nutrients to the sediment. However, the five studied sites are macro- to meso-tidal sandy bays. In these types of bay, only a small part of the detrital organic matter produced from degradation is incorporated into the sediment as showed by Chardy (1993) for Saint-Brieuc Bay. 
In sandy and estuarine sites on the north-western coast of France, Monbet et al. (1991),

Douchement (1987) and Lerat (1990) measured monthly release rates of ammonium, nitrate and phosphorus by the sediment. These values have been compiled and compared to other values from the literature (Bailey, 2005) for sandy sites to estimate mean values used in the biological model.

In the biological model, a constant sedimentary flux of ammonium $\left(S E D_{N H 4}\right)$, nitrate $\left(S E D_{N O 3}\right)$ and dissolved phosphorus $\left(S E D_{P O 4}\right)$ directed towards the water column was thus included in the intertidal zone and conditioned on water height to limit nutrient fluxes from the sediment. No flux was considered if the water height was greater than $2 \mathrm{~m}$ which corresponds approximately to the 3-4 h after the beginning of submersion (Usui et al., 1998).

The seasonal change in Ulva biomass, which is assumed to settle eventually on the sea bottom, is strongly influenced by a self-shading biomass factor (ulvasurf). With this factor, only the superficial part of the deposit needs to be accounted for when calculating Ulva growth. At the beginning of the bloom (in April), Ulva biomass is small, so that self-shading does not affect its growth. As soon as Ulva concentrations increase (mid-May to June), selfshading plays an important role in limiting total production. Experiments done at the Marine Algae Technology Centre (CEVA) show that a self-shading effect from the biomass occurs at densities greater than $1 \mathrm{~kg} \cdot \mathrm{m}^{-2}$ (ww) (data not shown). The self-shading biomass parameter depends on the surface-specific biomass (ulvasurf $f_{0}$ ) which can be used to take into account the self-shading effect in the computation of Ulva biomass. It was expressed as

$$
\left\{\begin{aligned}
\text { ulvasurf } & =\text { ulvasurf }_{0} / X 8 & & \text { if } X 8>\text { ulvasurfo }_{0} \\
& =1 & & \text { otherwise }
\end{aligned}\right.
$$

The following subset of differential equations, which were coupled to the transport model, allowed the computation of each state variable:

$$
\mathrm{d} X 1 / \mathrm{dt}=k_{\text {remN }} \times X 4-(X 1 /(X 1+X 2)) \times\left(V_{\text {Nulva }} \times X 8 \times \text { ulvasurf } / H\right)-k_{\text {nitrif }} \times X 1
$$




$$
\begin{aligned}
& \mathrm{d} X 2 / \mathrm{dt}=k_{\text {nitrif }} \times X 1-(X 2 /(X 1+X 2)) \times\left(V_{\text {Nulva }} \times X 8 \times \text { ulvasurf } / H\right) \\
& \mathrm{d} X 3 / \mathrm{dt}=k_{\text {remP }} \times X 5-V_{\text {Pulva }} \times X 8 \times \text { ulvasurf } / H \\
& \mathrm{~d} X 4 / \mathrm{dt}=\left(m_{\text {ulva }} \times X 6 / H\right) / 0.014-k_{\text {remN }} \times X 4 \\
& \mathrm{~d} X 5 / \mathrm{dt}=-k_{\text {remP }} \times X 5+\left(m_{\text {ulva }} \times X 7 / H\right) / 0.031 \\
& \mathrm{~d} X 6 / \mathrm{dt}=0.014 \times V_{\text {Nulva }} \times X 8 \times \text { ulvasurf }-m_{\text {ulva }} \times X 6 \\
& \mathrm{~d} X 7 / \mathrm{dt}=0.031 \times V_{\text {Pulva }} \times X 8 \times \text { ulvasurf }-m_{\text {ulva }} \times X 7 \\
& \mathrm{~d} X 8 / \mathrm{dt}=\left(\mu_{\text {ulva }} \times \text { ulvasurf }-m_{\text {ulva }}\right) \times X 8
\end{aligned}
$$

The conceptual model, state variables and other variables used in the mathematical formulae are presented in Figure 6, Table 2 and Table 3, respectively.

The distribution of washed up Ulva (Figure 7) was determined from the average distribution of algae calculated from data recorded each year since 2002. Initial Ulva density was set to a uniform value of $20 \mathrm{~g}$ dry weight (dw), which can be considered as a realistic value before bloom onset.

\subsection{Calibration and validation of the hydrodynamic and biological models}

Due to the number of study sites and the cost of sensor deployment to measure continuously variables, such as water depth, instantaneous currents, temperature and salinity, the validation of the hydrodynamic model was only performed by comparing the predicted tidal heights with those provided by the French Naval Hydrographic and Oceanographic Service (SHOM). The file provided by SHOM, which integrates the first 115 tidal harmonic constituents, was calculated from the 2D Telemac model coupled with a large set of in situ data. The comparison was done considering a real tide occurring in January 1996 and representing a succession of two neap and spring tides. The MARS model and the SHOM tidal signal used for the comparison were produced using a sampling output rate of $10 \mathrm{~min}$ (about 4500 points for each series). The hydrodynamic model was calibrated by adjusting the Strickler coefficient 
(i.e. bottom friction coefficient) so as to minimise the difference between the model and the SHOM tidal signals in terms of water level and phase difference.

Calibration of the biological model was mainly based on the seasonal variation of the maximum nitrogen uptake rate $\left(\mathrm{V}_{\operatorname{maxN}}\right)$ and the half-saturation constant for nitrogen $\left(\mathrm{K}_{\mathrm{N}}\right)$ to reproduce the internal nutrient quotas measured in situ for each site. These parameters are shown for each bay in Figure 8. Values were consistent with those found in the literature (O’Brien and Wheeler, 1987; Pedersen, 1994; Campbell, 1999 and Runcie, 2003). However, to our knowledge, in situ seasonal changes in kinetic parameters has not been studied, although this pattern was in good agreement with the decrease in the physiological capacities of Ulva spp. during the summer when stress conditions are the highest (desiccation, nutrient limitation, self-shading, etc.). For instance, Kim et al. (2004) showed that photosynthetic performance of Ulva pertusa is lower in the summer than in the spring. Rivers and Peckol (1995) obtained the same result for Ulva lactuca. To assess the effect of seasonal variation in $\mathrm{V}_{\max }$ and $\mathrm{K}_{\mathrm{N}}$, the changes in biomass and internal nitrogen quotas were compared, for each site, with those obtained without time variation for the maximum of nitrogen uptake rate $\left(\mathrm{V}_{\operatorname{maxN}}=200 \mu \mathrm{mol} \mathrm{g}{ }^{-1}\right)$ and the half-saturation constant for nitrogen uptake $\left(\mathrm{K}_{\mathrm{N}}=30 \mu \mathrm{mol} \mathrm{dm}-\right.$ ${ }^{3}$ ). Parameters values were derived from Ménesguen et al. (2006).

Self-shading was also a site-specific parameter and was used to reproduce biomass evolution in accordance with algal cover recorded annually in situ at each site by aerial surveys. The biological model was validated by comparing the predicted algal biomass with actual algal biomass recorded in situ and derived from the algal cover survey carried out by CEVA for each simulated year.

\subsection{Sensitivity analysis}


A one-way sensitivity analysis was adopted to determine which parameters had the greatest influence on model results. The sensitivity analysis involved varying the value of a parameter by a given amount, set at $\pm 20 \%$ for $V_{\max }, K_{N}, I_{\text {optulva }}, f_{T 2}^{0}$, ulvasurfo, $k_{\min N}^{0}, k_{\min P}^{0}, k_{n i t r i f}^{0}$, $m_{u l v a}^{0}, \mu_{\max u l v a}$, at $\pm 2^{\circ} \mathrm{C}$ for the parameters $T_{\text {opt min }}$ and $T_{\text {opt max }}$, and at a factor of 0.5 and 2 for initial biomass. Deviation from the baseline simulation was quantified for total biomass and internal nitrogen quotas and was expressed as described in Brush and Nixon (2010), i.e. as the mean relative deviation from the baseline simulation:

$\%$ impact $=100 \% \times\left(X_{\text {sensitivity }}-X_{\text {baseline }}\right) / X_{\text {sensitivity }}$

where $\mathrm{X}_{\text {baseline }}$ represents the biomass or the internal nitrogen quota for the baseline simulation and $\mathrm{X}_{\text {sensitivity }}$ the biomass or the internal nitrogen quota for the sensitivity simulation. For each sensitivity run, the time-series used for the calculation of the mean relative deviation was based on 183 outputs (one model output per day from the beginning of April to the end of September) and was computed across all spatial elements (pixels) for biomass and at three fixed points for the internal nitrogen quota.

Due to the large amount of simulations performed, only one site was used for these numerical experiments. The model of Lannion Bay (a strong tidally stirred ecosystem, numerous rivers, heavy macroalgal bloom) appeared to be the best candidate to test sensitivity and the most representative site of the five studied.

\subsection{Tracking the nitrogen source in Ulva}

The numerical technique used for assessing the nitrogen source in Ulva was based on Ménesguen et al. (2006). The method consists in doubling the subset of differential equations relative to the nitrogen cycle. The state variables under focus were ammonium, nitrate, detrital organic nitrogen and Ulva nitrogen pool. Hence, the same advection/dispersion reaction equation was used for each of the four state variables, but applied to the product of the nitrogen state variable $(\mathrm{Xi})$ times the proportion of nitrogen originating from the $j$ th tracked 
source (Yji). In our case, sources to be tracked were the river loadings, the open boundaries and the sediment. Although this method is quite demanding in terms of calculation time, it has the advantage of being perfectly conservative. Inorganic nutrient loadings for the $j$ th tracked source were set to 1 during the whole simulation whereas the remaining sources were set to 0 . Initial conditions for the Yji fraction at source locations were set to zero. Results involving the nitrogen budget were obtained when steady states were reached (typically as of early May).

\subsection{Nitrate load reduction scenarios}

Reduction scenarios were studied by limiting the nitrogen loadings (sum of ammonium and nitrate forms) to $5,10,15,20,25$ and $30 \mathrm{mg} \mathrm{l}^{-1}$ (only 5,10 and $15 \mathrm{mg} \mathrm{l}^{-1}$ were tested for Saint-Brieuc Bay). For a given year and reduction scenario, it was necessary to run the model twice (the first run to assess the percentage of Ulva biomass reduction calculated on the August-September period, the second run to apply this reduction to the initial Ulva biomass). Using this method, we can estimate the long-term effect of nitrogen reduction by evaluating the progressive erosion of the initial Ulva stock. The estimated percentage of biomass reduction from August to September in the first year was used to determine the initial biomass for the second year. Initial biomass conditions for the second year were obtained by removing the algal cover in some grids according to the estimated percentage reduction in the previous year. The algal cover removal algorithm cleaned up the grids located in the upper zone of the foreshore first. The percentage of biomass reduction was estimated using the ratio between the total biomass relative to the baseline simulation (i.e. without nitrogen limitation) from August to September and the total biomass from scenarios with nitrogen limitation were integrated from August to September. 
4. Results

\subsection{Hydrodynamic model validation}

For each bay, the time series of simulated sea surface elevation was graphically compared to the tidal height predicted by the SHOM data. From these data, the phase angle difference and the relative error on the tidal range were calculated. As an example, graphs are shown for Lannion Bay (Figure 9). For other sites, results are compiled in Table 4. Timing discrepancy between SHOM data and our model varied from $9.6 \mathrm{~min}$ for Douarnenez bay to $21.3 \mathrm{~min}$ for Saint-Brieuc bay. Relative error of tidal range was generally around $15 \%$. For all bays, timing discrepancy and relative error of tidal range increased during neap tide and decreased during spring tide, indicating that spring tide was better modelled than neap tide.

\subsection{Biological calibration and validation}

Since 2002, the CEVA has monitored algal cover and internal nitrogen pool monthly from April to October. These data sets allowed a precise calibration and validation of the biological model by comparing model and measurements for a given year (2002 for Saint-Brieuc Bay, 2004 for La Fresnaye Bay and 2005 for Douarnenez, Guissény and Lannion Bays). Results of the calibration process based on internal nitrogen pool and the validation process based on total biomass are presented in Figure 10, with and without temporal variation in the maximum nitrogen uptake rate and the half-saturation constant for nitrogen. The introduction of seasonal variation for these two parameters clearly improved model predictions, especially for Guissény and Douarnenez Bays and to a lesser extent for Saint-Brieuc Bay. When the values of $\mathrm{V}_{\operatorname{maxN}}$ and $\mathrm{K}_{\mathrm{N}}$ were assumed to be constant, the model was not able to reproduce the seasonal variation in nitrogen pool in Ulva tissues and showed no nitrogen limitation from June to August. The change in simulated total biomass compared to algal cover measurements for these three sites was in turn overestimated. In the Lannion and La Fresnaye Bays, the 
difference between results with and without temporal variation in $\mathrm{V}_{\operatorname{maxN}}$ and $\mathrm{K}_{\mathrm{N}}$ was smaller because algae in these bays are naturally limited during summer by the availability of dissolved nitrogen. With seasonal variation in $\mathrm{V}_{\operatorname{maxN}}$ and $\mathrm{K}_{\mathrm{N}}$, the change in algal biomass showed a good qualitative fit with the model, with a coefficient of determination $\left(\mathrm{R}^{2}\right)$ greater than 0.68 between the in situ data and the model. There was a good fit between the modelled and the observed growth period for Douarnenez and Saint-Brieuc Bays. For Lannion Bay and La Fresnaye Bay, there was a lag in algal growth predicted by the model in comparison with data recorded in situ. This is probably due to an underestimation of initial biomass. In Guissény Bay, from May to August, modelled algal growth was higher than actually recorded. This site appeared to have a specific behaviour compared to the other sites, with a longer growing phase (from May to August). To ensure that there was a good quantitative fit between biomass and the model, the relationship between measured algal cover (assessed by aerial survey) and modelled algal biomass was calculated for each site and compared with the one deduced from field data available for the same sites (Figure 11). In situ data showed that Ulva cover (ha equivalent to $100 \%$ algal cover, i.e. an area of 1 ha $50 \%$ covered by algae is equal to an area of $1 \times 50 \%=0.5$ ha equivalent to $100 \%$ algal cover) had to be multiplied by 52 to obtain the corresponding wet biomass ( $\mathrm{t}$ ). Modelled data showed that the relationship between algal cover and biomass ( $\mathrm{t}$ ) stayed in the range of in situ measurements for SaintBrieuc, La Fresnaye, Guissény and Lannion Bays. In Douarnenez Bay, despite a significant correlation showing a good qualitative representation, the total simulated biomass appeared to be overestimated (as shown in Figure 11) due to overestimation of initial biomass. Regarding internal nitrogen pool used for calibration (Figure 10), the model followed the general pattern measured in each bay with $\mathrm{R}^{2}$ ranging from 0.46 (Douarnenez) to 0.85 (La Fresnaye).

\subsection{Sensitivity analysis}


The relative mean deviation estimated from biomass and the internal nitrogen quota in Lannion Bay is illustrated in the form of a Tornado diagram (Figure 12). Modelled biomass and nitrogen quotas were only weakly sensitive $(<10 \%)$ to changes in the parameters $V_{\max N}$,

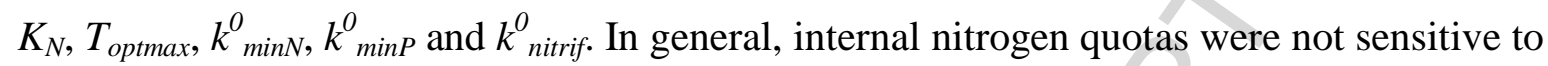
the increase or the decrease in key parameters because the nitrogen pool in Ulva is mainly controlled by the nitrogen fluxes coming from rivers, which were held stable in the sensitivity analysis. Biomass was found to be moderately sensitive to changes in the other parameters, i.e. $\mu_{\text {max ulva }}$, initial biomass, $f_{T 2}^{0}, m_{u l v a}^{0}, T_{\text {optmin }}, I_{\text {optulva }}$, ulvasurf . These experiments expectedly revealed that the maximal growth rate was the most influential parameter in the model. Interestingly, the introduction of an increase or a decrease in seasonal variation in the maximum nitrogen uptake rate $\left(V_{\max N}\right)$ and the half-saturation constant for nitrogen $\left(K_{N}\right)$, used to calibrate the biological model, had little influence on the model, and the most influential parameter for these factors was the introduction of a seasonal pattern.

\subsection{Nitrogen source in Ulva}

Figure 13 shows the contribution of rivers, sediment, water-treatment plants and open ocean to the Ulva nitrogen budget from May to October. Nitrogen tracking showed firstly the main nitrogen sources and secondly that green tide was mainly controlled by local rivers. On average, over the whole period from May to September, the nitrogen pool in Ulva from Lannion Bay originated from two rivers: Yar (31\%) and Douron (27\%). The Roscoat and seawater contributed respectively to $14 \%$ and $16 \%$ of the nitrogen pool in Ulva. In Douarnenez Bay, from May to September, the Lapic, Ris and Port Rhu Rivers were responsible for $54 \%$ of the Ulva nitrogen pool. For the bays of La Fresnaye, Guissény and Saint-Brieuc, the main nitrogen contribution depended only on one river (Frémur, 56\%; Quillimadec, 76\% and Gouet, 53\%; respectively). Results per season showed that the natural open sea was a significant source of Ulva nitrogen pool in in early spring ranging from 20 to 
more than 50\% depending on the site. From May to October, nitrate from seawater contributed from 9 to $28 \%$ of the total nitrogen pool in Ulva. Whatever the site, the constant sedimentary fluxes contributed to less than $10 \%$ of the total Ulva nitrogen pool. To illustrate the spatial influence of nitrogen from rivers on the intertidal zone, a map of the local contributions to Ulva nitrogen pool of various rivers that empty into Douarnenez Bay is shown in Figure 14. This showed that every river had a local impact on Ulva nitrogen pool and therefore on Ulva growth. Thus, scenarios of nitrogen reduction were designed by decreasing nitrogen from all rivers to explore the impact of reduced nitrogen input on macroalgal blooms within a given bay.

\subsection{Nitrogen load reduction scenarios}

Nitrate concentrations and nitrate fluxes from in situ measurements in the main rivers of each bay are presented in Table 5. Nitrate concentrations in rivers are less variable than fluxes are (fluxes are directly dependant on the annual/seasonal rainfall), making it possible to compare sites between different years. It is important to note that total dissolved inorganic nitrogen carried by rivers for the five studied sites was mainly found in the nitrate form. The ammonium form represented only 1 to $2 \%$ of the total nitrogen flux. As a consequence, nitrogen reduction scenarios were based only on nitrate reduction. Among all sites under study, nitrate concentrations varied from $20.3 \mathrm{mg} \mathrm{l}^{-1}$ (Gouessant in La Fresnaye Bay) to 58.3 $\mathrm{mg}^{-1}$ (Quillimadec in Guissény Bay). In spite of their proximity, rivers at a given study site showed wide variation in nitrate concentrations, e.g. for La Fresnaye Bay, the concentration in Frémur River was two-fold greater than that of Rat River (50.09 and $25.80 \mathrm{mg} \mathrm{l}^{-1}$, respectively). Results of the different scenarios of nitrogen reduction are presented in Table 6. To reach the goal of $50 \%$ reduction in algal biomass, nitrate concentration in rivers must be reduced from 5 to $15 \mathrm{mg} \mathrm{l}^{-1}$, depending on the site. La Fresnaye Bay was the most responsive 
site: river nitrate loadings as high as $15 \mathrm{mg}^{-1}$ result in a reduction of algal biomass by more than half. Contrary to La Fresnaye, Saint-Brieuc Bay requires a drastic reduction in river nitrate loadings: a concentration of $5 \mathrm{mg}^{-1}$ is needed to reach the same objective of $50 \%$ seaweed biomass reduction. Douarnenez, Guissény and Lannion Bays are intermediate sites with targets of nitrate concentrations of $10-15 \mathrm{mg} \mathrm{l}^{-1}, 10 \mathrm{mg} \mathrm{l}^{-1}$ and $10 \mathrm{mg} \mathrm{l}^{-1}$, respectively to reduce the current algal biomass by half.

\section{Discussion}

\subsection{Model accuracy}

Our results show that the model satisfactorily simulated the functioning of every bay regarding their hydrodynamic (for sea surface height) and biological (for total biomass and nitrogen pools) characteristics, except for Douarnenez Bay where biomass was overestimated when compared with in situ algal cover converted to biomass. This overestimation was directly due to the initial stock of washed up Ulva which differed greatly in Douarnenez Bay in 2005 compared to the mean stock calculated with data from 2002 to 2007 . Using an initial map based on the spatial distribution of Ulva during the period of maximum biomass in 2005 may lead to a more consistent result between the model and observations for this bay. Thus, initial maps of washed up Ulva (in connection with initial biomass) are an important component of model success as shown in the sensitivity analysis and in Pastres et al. (1999). No transport mechanism was integrated in our model, contrasting with the original model (Ménesguen et al., 2006). Preliminary experiments indicated that the classical formulation of the Ulva transport model based on the Krone and Partheniades approach did not reproduce algal transport and settling. For instance, numerical experiments carried out for Lannion and Saint-Brieuc Bays showed that the simulated biomass of washed up Ulva was definitively washed up beyond the upper zone of the foreshore and that the transport model was unable to 
concentrate a fraction of the bloom at low tide in the nearshore lower zone. However, the lack of a transport model did not prevent a realistic representation of the Ulva bloom at a seasonal scale. Monitoring the algal stock in Binic Bay (western part of Saint-Brieuc Bay) for four tidal cycles showed that algal biomass distribution is virtually the same during calm weather before and after high or low tides during spring and neap tides (CEVA, 2009). In Douarnenez Bay, which has an important infralittoral Ulva stock (Merceron and Morand, 2004), the use of a robust physical transport model may be useful for simulating Ulva accumulation on the beach and Ulva removal from the system during windy events. In Lannion and Guissény Bays, the recorded infralittoral biomass is moderate (respectively $16 \%$ and $18 \%$ of the total biomass compared to 53\% for Douarnenez Bay). In Saint-Brieuc and La Fresnaye Bay, infralittoral biomass can be considered negligible (respectively $2 \%$ and $3 \%$ of the total biomass). Except for Douarnenez Bay, the use of a transport routine will not greatly improve the modelling of algal blooms.

The phytoplankton compartment was not considered in this model. As shown by Ménesguen and Piriou (1995), Ulva biomass correlates well with summer nitrogen loadings carried by rivers and discharged in open coastal waters of Brittany. As Ulva biomass is located in the intertidal zone where rivers end, macroalgae can utilise the nitrogen in river plumes. This suggests that competition between Ulva and phytoplankton for nutrients is limited in such ecosystems. However, if this model were to be used in estuaries, then phytoplankton should be considered. In estuarine ecosystems, Brush and Nixon (2010) showed that the predicted algal biomass was highly overestimated when phytoplankton was absent, especially at the summer peak.

In addition, grazing was not taken into account in our model. Grazing pressure has been widely studied on muddy sites. The impact of grazing has been shown through the top-down control of macroalgae blooms (Lotze and Worm, 2002). Herbivores can also enhance Ulva 
growth by reducing microalgal biofilm fouling on macroalgal blades (Guidone et al., 2010). To our knowledge, no published work deals with grazing pressure on open sandy sites. Moreover, sand is not an appropriate substrate for gastropods which are the main macroalgae grazers.

In regard to open coastal ecosystems, our model takes into account the main driving parameters behind green tide events.

\subsection{Using models as management tools}

The methodology in this study was developed to provide practical recommendations for stakeholders; it was based on (1) the analysis of nitrogen river fluxes; (2) the simulated accumulation of sources of Ulva nitrogen pool (nitrogen tracking technique) and (3) on the simulation scenarios of decreases in river nitrate concentrations.

Our modelling study showed that nitrate reduction is an effective way to reduce Ulva blooms in the shallow bays of the Brittany coast. Nutrient limitation in the marine environment has been often discussed (Smith, 1984) and studies that monitor the internal nitrogen and phosphorus pool in Ulva show either nitrogen or phosphorus limitation (Viaroli et al., 2005; Riisgard et al., 2008), a co-limitation of both nutrients (Villares and Carballeira, 2003) or a switch between nitrogen and phosphorus limitation according to season (Wheeler and Bjornaster, 1992). Thus, modelling is an important tool for stakeholders to guide and justify their management choices. The MARS-Ulves model also identified the main sources of nitrates as well as the season in which they played a role in macroalgal development. The model shows that nitrogen from the natural open sea is of limited importance compared with anthropogenic inputs from rivers. These results are consistent with those obtained by Ménesguen et al. (2006) in which marine inputs accounted for $15 \%$ of the total nitrogen pool in Ulva. Other studies showed similar results with a high contribution of nitrogen from river 
streams to the global nitrogen budget in estuaries (Lacroix et al., 2007; Neumann, 2007;

Timmermann et al., 2010). However, the natural open sea makes a high quantity of nitrogen during spring mainly due to the concentration in $\mathrm{NO}_{3}$ at marine boundaries: $2.52 \mu$ mol. ${ }^{-1}$ in spring (average from April to June) and $0.05 \mu$ mol. $1^{-1}$ in summer (average from July to September). Winter nutrient enrichment of the natural open sea is due to the reduced primary production during this unfavourable season (low photoperiod, low temperature) coupled with stormy weather which contributes to the mixing and the re-enrichment of the water column. Thus, the seasonal patterns of the different nitrogen sources indicates that the reduction in nitrate in rivers will negatively influence algal development during summer, thereby affecting the residual winter algal stock. In addition, Kamermans et al. (1998) showed the residual Ulva stock in winter plays an important role in the spring initiation of the Ulva bloom. Therefore, in conjunction with a winter decrease, a reduction in the spring bloom can be expected in the long term.

Moreover, this model can be used to set realistic targets for enhancing water quality. In Saint-Brieuc Bay for the simulated year 2005, the model showed that a target level in nitrate concentrations lower than $10 \mathrm{mg} \mathrm{l}^{-1}$ in rivers is necessary to halve the current algal biomass in the August-September period. In 2011, a drastic decrease in green tide events was observed with an algal area reduction of 64\% in August-September 2011 compared to the same time period in 2005 . This decrease was related to the low inorganic nitrogen fluxes (16 t). The range of nitrate reduction predicted by the model for 2005 (between 5 and $10 \mathrm{mg}^{-1}$ ) is equal to a predicted total flux of between 9 and $18 \mathrm{t}$ in dissolved inorganic nitrogen (value obtained by multiplying the flux observed in 2005 by the nitrate concentration predicted by the model). The magnitude of the targeted reduction in algal biomass predicted by the model was consistent with the observations made in 2011. 
The Loire-Brittany Water Agency used a water quality assessment tool to rank different classes of water quality based on data from biology and water use (Oudin et al., 1999). Results of this classification showed that good water quality requires nitrate concentrations of $\leq 10 \mathrm{mg} \mathrm{l}^{-1}$ in rivers for a minimum of $90 \%$ of measurements taken all year long, which is in good agreement with our results.

Results obtained in this work in terms of nitrogen quality targets can guide watershed models. Watershed models can simulate the nitrogen concentrations of drainage water under various agricultural land uses and are used to choose the best agricultural practices to achieve nutrient reduction in rivers. Such models are regularly developed and applied to small catchments in Brittany by the French National Institute for Agricultural Research (INRA). For instance, Ruiz et al. (2002) studied the effect of agricultural practices on nitrate concentration in stream water in small catchments in Brittany ; Beaujouan et al. $(2001 ; 2002)$ modelled the effect of the spatial distribution of agricultural practices on nitrogen fluxes in rural catchments and developed a hydrological model dedicated to topography-based simulation of nitrogen transfer and transformation. Combining the two approaches (marine and terrestrial models) is clearly necessary to guide stakeholders in their management decisions.

\section{Conclusion}

Modelling Ulva green tides at five sites in Brittany showed that nitrate concentrations in rivers should be restricted to between $5 \mathrm{mg} \mathrm{l}^{-1}$ and $15 \mathrm{mg} \mathrm{l}^{-1}$, depending on the study site, to reduce Ulva biomass by at least half. Numerical nitrogen tracking showed that nitrogen from rivers was largely responsible for green tides with a significant contribution of nitrogen coming from oceanic water masses in the spring. Our method also highlighted the need to reduce nitrogen simultaneously in all rivers, because each one contributes to the excess supply of nutrients that sustain and promote green algae growth. 
Lastly, working on several bays with the same model highlighted that each bay has a particular functioning, which renders it more or less sensitive to reduction in nitrate fluxes. This information is important for stakeholders who must predict the time required to obtain results after the implementation of water quality restoration steps.

\section{Acknowledgments}

This work was supported by the Brittany Regional Council, the four Brittany local councils (Côtes d'Armor, Finistère, Morbihan and Ille-et-Vilaine) and the Loire-Brittany Water Agency. We would like to thank Sylvain Ballu (CEVA) for his help with the nitrogen flux data. We are also grateful to Philippe Cugier (IFREMER) for his collaboration on technical aspects of the model and Patrick Dion (CEVA) for his biological expertise. Thanks also to Jean-François Sassi and Laure Noël (CEVA) for their careful reading of the manuscript. We would like to thank all the people who participated in the extensive collection of field data. Finally, we are grateful to the reviewers and the editor in chief for their remarks which substantially improved the manuscript. 


\section{References}

Bailey, E., 2005. Measurements of nutrient and oxygen fluxes in estuarine and coastal marine sediments: Literature review and data report, Technical Report Series Ref. No. [UMCES] CBL 05-091, University of Maryland Center for Environmental Science, Chesapeake Biological Laboratory, Solomons, MD, p. 36.

Beaujouan, V., Durand, P. Ruiz, L. 2001. Modelling the effect of the spatial distribution of agricultural practices on nitrogen fluxes in rural catchments. Ecol. model. 137, 93-105

Beaujouan, V., Durand, P., Ruiz, L., Aurousseau, P., Cotteret, G. 2002. A Hydrological model dedicated to Topography-based simulation of Nitrogen Transfer and Transformation.

Rationale and application to the geomorphology-denitrification relationship. Hydrol. Process. 16, 493-507.

Briand, X., 1989. Prolifération de l'algue verte Ulva sp. En baie de Lannion (France) : étude d'une nuisance et de son traitement par fermentation anaérobie, Thèse de $3^{\text {ème }}$ cycle, Univ. Lille I, France, p. 210.

Brock, T.D., 1981. Calculating solar radiation for ecological studies. Ecol. Model. 14, 1-19.

Brush, M.J., Nixon, S.W., 2010. Modeling the role of macroalgae in a shallow sub-estuary of Narragansett Bay, RI (USA). Ecol. Model. 221, 1065-1079.

Cabrita, M.T., Catarino, F., Vale, C., 1998. The effect of tidal range on the flushing of ammonium from intertidal sediments of the Tagus estuary, Portugal. Oceanol. Acta 22, 291 302.

Campbell, S.J., 1999. Uptake of ammonium by four species of macroalgae in Port Phillip Bay, Victoria, Australia. Mar. Freshwater Res. 50, 515-522

Campling, P., Terres, J.M., Vande Walle, S., Van Orshoven, J., Crouzet, P., 2005. Estimation of nitrogen balances from agriculture for EU-15: spatialisation of estimates to river basins using the CORINE Land Cover. Phys. Chem. Earth. 30, 25-34.

CEVA, 2009. Evaluation des besoins d'observations complémentaires pour valider la faisabilité d'un ramassage massif à but de déstockage sur le site à marées vertes de BinicEtables. Rapport final, $24 \mathrm{p}$.

CEVA, 2011. Contrôle de surveillance DCE 2010. Suivi des blooms de macroalgues opportunistes. Rapport final, $51 \mathrm{p}$.

Chardy, P., Gros, P., Mercier, H., Monbet, Y., 1993. Benthic carbon budget for the Bay of Saint-Brieuc (Western Channel). Application of inverse method. Oceanol. Acta, 16(5-6), 687694.

Dion, P., Le Bozec, S., 1996. The French Atlantic coasts. In: Schramm, W., Nienhuis, P.H. (Eds), Marine benthic vegetation, Recent changes and the effects of eutrophication, Berlin, Heidelberg, pp. 251-264. 
Douchement, C., 1987. Chimie de deux milieux marins anoxiques eaux hydrothermales et eaux interstitielles des sédiments. Méthodologie des prélèvements et des analyses des composés de l'azote, du phosphore, et du silicium. Dynamique de leur circulation en sédiments côtiers, Thèse $3^{\text {éme }}$ cycle, Univ. de Bretagne Occidentale, France, 165 p.

Droop, M.R., 1968. Vitamin B12 and marine ecology, IV. The kinetics of uptake, growth and inhibition in Monochrysis lutheri. J. Mar. Biol. Assoc. U.K. 48, 689-733

Guidone, M., Thornber,C.S., Field, E. 2010. Snail grazing facilitates growth of a bloomforming alga. Mar. Ecol. Prog. Ser. 420, 83-89.

Henriksen, K., Hansen, J.I., Blackburn, T.H., 1981. Rates of nitrification, distribution of nitrifying bacteria, and nitrate fluxes in different types of sediment from Danish waters. Mar. Biol. 61, 299-304.

Hernandez, I., Peralta, G., Perez-Llorens, J.L., Vergara, J.J., Niell, F.X. 1997. Biomass and dynamics of growth of Ulva species in Palmones river estuary. J. Phycol. 33, 764-772.

Howarth, R.W., 1993. The role of nutrients in Coastal Waters. In: National Academy Press (Ed.), Managing Wastewater in Coastal Urban Areas. Committee on Alternatives for Wastewater Management in Coastal Urban Areas, Washington, D.C., pp. 177-202.

Jeffrey, D.W., Brennan, M., Jennings, E., Madden, B., Wilson, J.G., 1995. Nutrient sources for in-shore nuisance macroalgae: the Dublin Bay case. Ophelia 42, 147161.

Kamermans, P., Malta, E.J., Verschuure, J.M., Lentz, L.F., Schrijvers, L. 1998. Role of cold resistance and burial for winter survival and spring initiation of an Ulva spp. (Chlorophyta) bloom in an eutrophic lagoon (Veerse Meer lagoon, The Netherlands). Mar. Biol. 131, 45-51.

Kim, K.W., Choi, T.S., Kim, J.H., Han, T., Shin, H.W., Garbary, D.J. 2004. Physiological ecology and seasonality of Ulva pertusa on a temperate rocky shore. Phycologia 43, 483-492.

Lacroix, G., Ruddick, K., Gypens, N., Lancelot, C., 2007. Modelling the relative impact of rivers (Scheldt/Rhine/Seine) and Western Channel waters on the nutrient and diatoms/Phaeocystis distributions in Belgian waters (Southern North Sea). Cont. Shelf Res. 27, 1422-1446.

Lazure, P., Dumas, F., 2008. An external internal mode coupling for a 3D hydrodynamical model for applications at regional scale (MARS). Adv. Water Resour. 31, 233-250.

Lerat, Y., 1990. Cycles annuels de la matière organique et des éléments nutritifs dans les sédiments d'un écosystème côtier (baie de Morlaix, France), interactions avec le compartiment pélagique. Thèse $3^{\text {éme }}$ cycle, Univ. de Bretagne Occidentale, 212 p.

Liu, D., Keesing, J.K., Dong, Z., Zhen, Y., Di, B., Shi, Y. Fearns, P. and Shi, P. 2010. Recurrence of the world's largest green-tide in 2009 in Yellow Sea, China: Porphyra yezoensis aquaculture rafts confirmed as nursery for macroalgal blooms. Mar. Pollut. Bull. 60, 1423-1432. 
Lotze, H.K., Worm, B., 2002. Complex interactions of climatic and ecological controls on macroalgal recruitment. Limnol. Oceanogr. 47, 1734-1741.

Luyten, P., De Mulder, T., 1992. A module representing surface fluxes of momentum and heat. MUMM's contribution to MAST-0050-C. Technical report 9. Management Unit of the Mathematical Models of the North Sea and Scheldt Estuary.

Lyngby, J.E., Mortensen, S., Ahrensberg, N. 1999. Bioassessment techniques for monitoring of eutrophication and nutrient limitation in coastal ecosystems. Mar. Pollut. Bull. 39, 212-223.

Malta, E.J., Verschuure, J.M. 1997. Effects of environmental variables on between-year variation of Ulva growth and biomass in a eutrophic brackish lake. J. Sea Res. 38, 71-84.

McGlathery, K.J., 2001. Macroalgal blooms contribute to the decline of seagrass in nutrientenriched coastal waters. J. Phycol. 37, 453-456.

Ménesguen, A., Cugier, P, Leblond, I., 2006. A new numerical technique for tracking chemical species in a multisource, coastal ecosystem applied to nitrogen causing Ulva blooms in the bay of Brest. Limnol. Oceanogr. 51, 591-601.

Ménesguen, A., Piriou, J.Y., 1995. Nitrogen loadings and macroalgal (Ulva sp.) mass accumulation in Brittany (France). Ophelia 42, 227-237.

Ménesguen, A., Salomon J.C., 1988. Eutrophication modelling as a tool for fighting against Ulva coastal mass blooms. in : "Computer modelling in ocean engineering", Schrefler \& Zienkiewicz (eds.), Proc. Internat. Conf., 19-22 Sept 1988, Venice (Italy), Balkema, Rotterdam, p.443-450.

Merceron, M., Antoine, V., Auby, I., Morand, P., 2007. In situ growth potential of the subtidal part of green tide forming Ulva spp. stocks. Sci. Total Environ. 384, 293-305.

Merceron, M and Morand, P. 2004. Existence of a deep subtidal stock of drifting Ulva in relation to intertidal algal mat developments. J. Sea Res. 52: 269-280.

Monbet, Z., Chardy, P., Gros, P., 1991. Benthic flux studies in the bay of St Brieuc (France). $10^{\text {th }}$ report of the Benthos Ecologic Working Group. Canada, pp. 32-52.

Nelson, T.A., Haberlin, K., Nelson, A.V., Ribarich, H., Hotchkiss, R., Van Alstyne, K.L., Buckingham, L., Simunds, D.J., Fredrickson, K. 2008. Ecological and physiological controls of species composition in green macroalgal blooms. Ecology 89, 1287-1298.

Neumann, T., 2007. The fate of river-borne nitrogen in the Baltic Sea - An example for the river Oder. Estuar. Coast. Shelf Sci. 73, 1-7.

Norkko, A., Bonsdorff, E., 1996. Rapid zoobenthic community responses to accumulations of drifting algae. Mar. Ecol. Prog. Ser. 131, 143-157.

O’Brien, M.C., Wheeler, P.A., 1987. Short-term uptake of nutrients by Enteromorpha prolifera (Chlorophyceae).J. Phycol. 23, 547-556. 
Oudin, L.C., Meybeck, M., Roussel, P., 1999. Système d'évaluation de la qualité de l'eau des cours d'eau. Rapport de presentation SEQ-Eau (version 1), Agence de l'eau Loire-Bretagne, France.

Pastres, R., Chan, K., Solidoro, C., Dejak, C., 1999. Global sensitivity analysis of a shallowwater 3D model. Comput. Phys. Commun., vol. 117, pp. 62-74.

Pedersen, M.F., 1994. Transient ammonium uptake in the macroalga Ulva lactuca (Chlorophyta): nature, regulation, and the consequences for choice of measuring technique. J. Phycol. 30, 980-986.

Pedersen, M.F., Borum, J., 1996. Nutrient control of algal growth in estuarine waters. Nutrient limitation and the importance of nitrogen requirements and nitrogen storage among phytoplankton and species of macroalgae. Mar. Ecol. Prog. Ser. 142, 261-272.

Piriou, J.Y., Ménesguen, A., 1990. Environmental factors controlling the Ulva sp. blooms in Brittany (France). In: Colombo, G., Ferrari, I., Ceccherelli, V.U., Rossi, R. (Eds.), Marine Eutrophication and Population Dynamics. Olsen and Olsen, Fredensborg, Denmark, pp. 111115.

Piriou, J.Y., Ménesguen, A., Salomon, J.C., 1991. The green tides of algae (Ulva sp.): necessary conditions, development and comparison of sites. In: Elliott, M., Ducrotoy, J.P. (Eds.), Estuaries and coasts: spatial and temporal intercomparisons, ECSA symposium, University of Caen, pp. 117-122.

Reay, W.G., Gallagher, D.L., Simmons, Jr. G.M., 1995. Sediment-water column oxygen and nutrient fluxes in nearshore environments of the lower Delmarva Peninsula, USA. Mar. Ecol. Prog. Ser. 118, 215-227.

Riisgard, H.U., Jensen, M.H., Rask, N. 2008. Odense Fjord and Kerteminde Fjord/Kertinge Nor. In: Schiewer, U., (Ed.) Ecology of Baltic Coastal Waters. Ecological Studies 197. Springer Verlag Berlin Heildelberg, pp. 363-396.

Rivers, J.S., Peckol, P., 1995. Summer decline of Ulva lactuca (Chlorophyta) in a eutrophic embayment: interactive effects of temperature and nitrogen availability? J. Phycol. 31: 223228.

Rocha, C., 1998. Rhytmic ammonium regeneration and flushing in intertidal sediments of the Sado estuary. Limnol. Oceanogr. 39, 573-579.

Ruiz, L., Abiven, S., Martin, C., Durand, P., Beaujouan, V. and Molénat, J., 2002. Effect on nitrate concentration in stream water of agricultural practices in small catchments in Brittany II- Temporal variations and mixing processes. Hydrol. Earth Sys. Sci. 6, 507-513.

Runca, E., Bernstein, A., Postma, L., DiSilvio, G., 1996. Control of macroalgae blooms in the Lagoon of Venice. Ocean Coast. Manag. 30, 235-257.

Runcie, J.W., Ritchie, R.J., Larkum A.W.D, 2003. Uptake kinetics and assimilation of inorganic nitrogen by Catenella nipae and Ulva lactuca. Aquat. Bot. 76: 155-174. 
Scanlan, C.M., Foden, J., Wells, E., Best, M.A., 2007. The monitoring of opportunistic macroalgal blooms for the water framework directive. Mar. Pollut. Bull. 55, 162-171.

Schwiderski, E.W., 1983. Atlas of ocean tidal charts and maps. Mar. Geod. 6, 219-265.

Smith, S.V. 1984. Phosphorus versus nitrogen limitation in the marine environment. Limnol. Oceanogr. 29, 1149-1160.

Solidoro, C., Pecenik, G., Pastres, R., Franco, D., Dejak, C., 1997. Modelling macroalgae (Ulva rigida) in the Venice lagoon: Model structure identification and first parameters estimation. Ecol. Model. 94, 191-206.

Timmermann, K., Markager, S., Gustafsson, K., E., 2010. Streams or open sea? Tracing sources and effects of nutrient loadings in a shallow estuary with a 3D hydrodynamicecological model. J. Mar. Sys. 82, 111-121.

Thornton, K.W., Lessen, A.S., 1978. A temperature algorithm for modifying biological rates. Trans. Am. Fish. Soc. 107, 284-287.

Usui, T., Koike, I., Ogura, N., 1998. Tidal effects on dynamics of porewater nitrate in intertidal sediment of a eutrophic estuary. J. Oceanogr. 54, 205-216.

Valiela, I., McClelland, J., Hauxwell, J., Behr, P.J., Hersh D., Foreman K., 1997. Macroalgal blooms in shallow estuaries: Controls and ecophysiological and ecosystem consequences. Limnol. Oceanogr. 42, 1105-1118.

Vanhoutte-Brunier, A., Fernand, L., Ménesguen, A., Lyons, S., Gohin, F., Cugier, P., 2008. Modelling the Karenia mikimotoi bloom that occurred in the western English Channel during summer 2003. Ecol. Model. 210, 351-376.

Viaroli, P., Bartoli, M., Azzoni, R., Giordani, G., Mucchino, C., Naldi, M., Nizzoli, D., Taje, L. 2005. Nutrient and iron limitation to Ulva blooms in a eutrophic coastal lagoon (Sacca di Goro, Italy). Hydrobiologia 550, 57-71.

Villares, R., A. Carballeira, 2003. Seasonal variation in the concentrations of nutrients in two green macroalgae and nutrient levels in sediments in the Rías Baixas (NW Spain). Estuar. Coast. Shelf Sci. 58, 887-900.

Vouvé, F., Guiraud, G., Marol, C., Girard, M., Richard, P., Laima, J.C., 2000. NH4 turnover in intertidal sediments of Marennes Oleron Bay (France): effect of sediment temperature. Oceanol. Acta 23, 575-584.

Water Framework Directive (WFD), 2000. Directive 2000/60/EC of the European Parliament and the Council of 23rd October 2000 establishing a framework for Community action in the field of water policy

Wheeler, P. A., Bjornsater, B.R. 1992. Seasonal fluctuations in tissus nitrogen, phosphorus, and N-P for 5 macroalgal species common to the pacific-northwest coast. Journal of Phycology 28, 1-6. 
Figure 1. Map of Brittany. Arrows indicate the bays that were modelled. 1- La Fresnaye Bay, 2- Saint-Brieuc Bay, 3- Lannion Bay, 4- Guissény Bay, 5- Douarnenez Bay (the black dot • indicates where water from the sewage treatment plant is discharged into the sea (at a depth of $10 \mathrm{~m}$ ). The black star indicates the location of the Estacade site and the black circle the location of the extraction of the generic offshore time-series for $\mathrm{NO}_{3}, \mathrm{NH}_{4}$ and $\mathrm{PO}_{4}$.
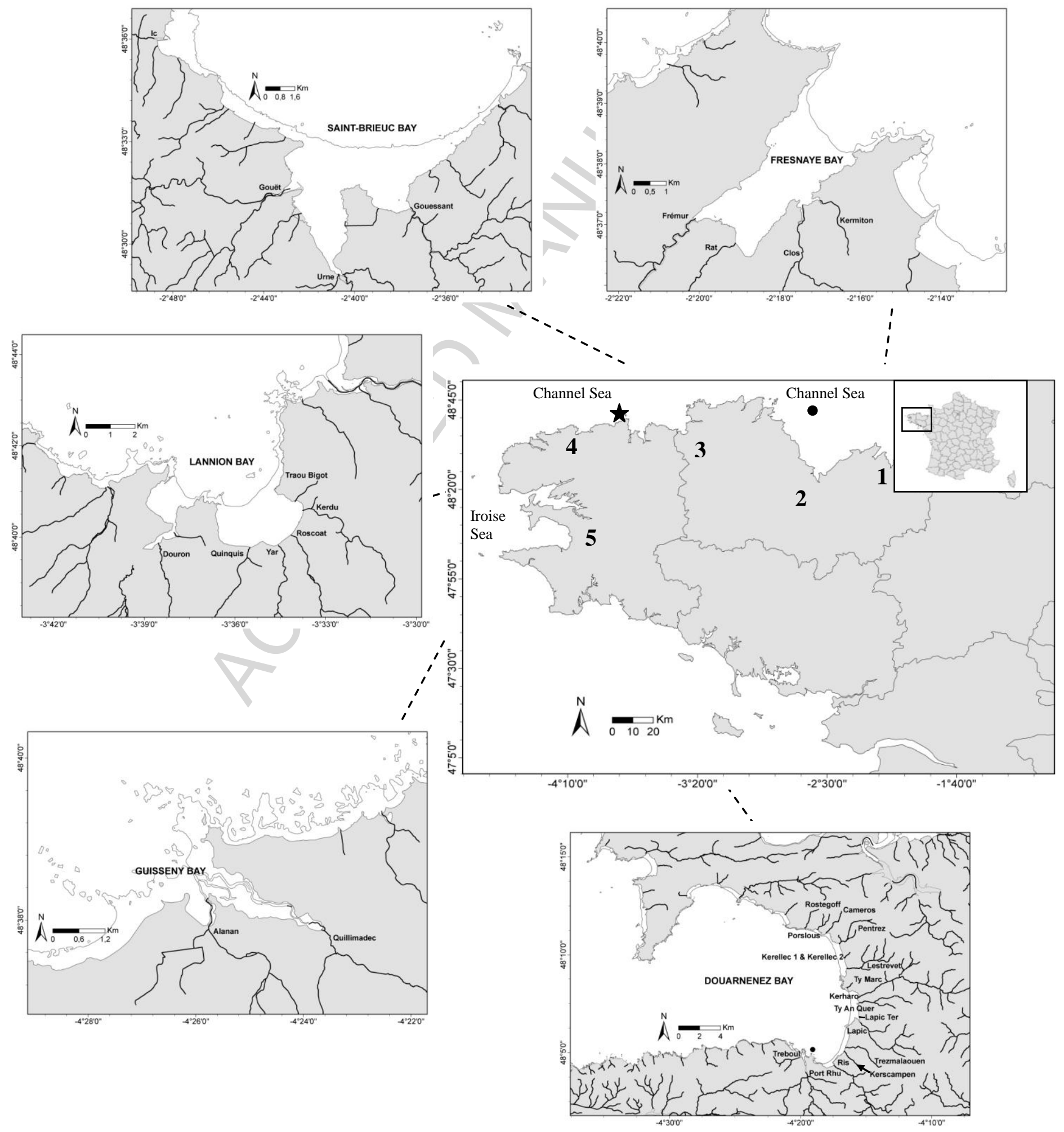
Figure 2: Illustration of the successive model domains used from the global scale (a) to the site scale (b). Three or four successive levels were used, depending on the site.

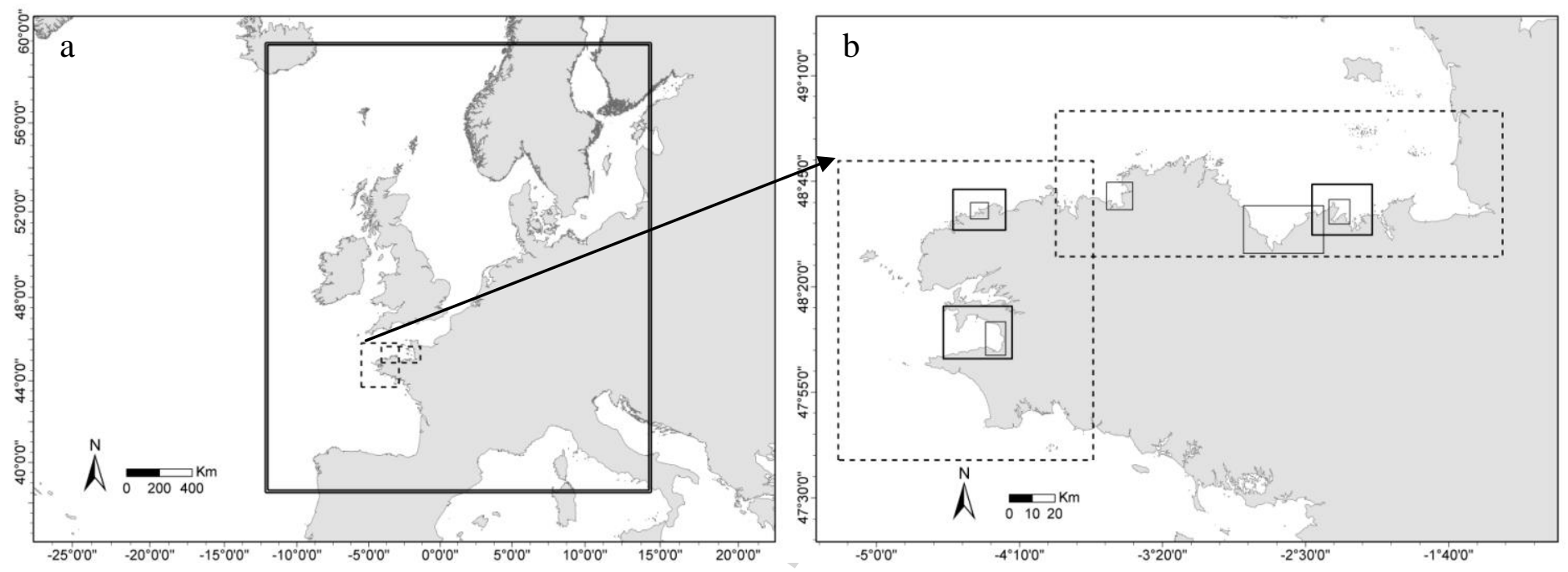


Figure 3: Concentration time-series: $\mathrm{N}-\mathrm{NO}_{3}$ (a) and $\mathrm{P}_{-} \mathrm{PO}_{4}$ (b) used in the model for the open sea (black line) and recorded in situ at the Estacade site based on a mean monthly value from 2005 to 2010 (grey line) (data provided by the Service d'Observation en Milieu Littoral, INSU-CNRS, Roscoff).
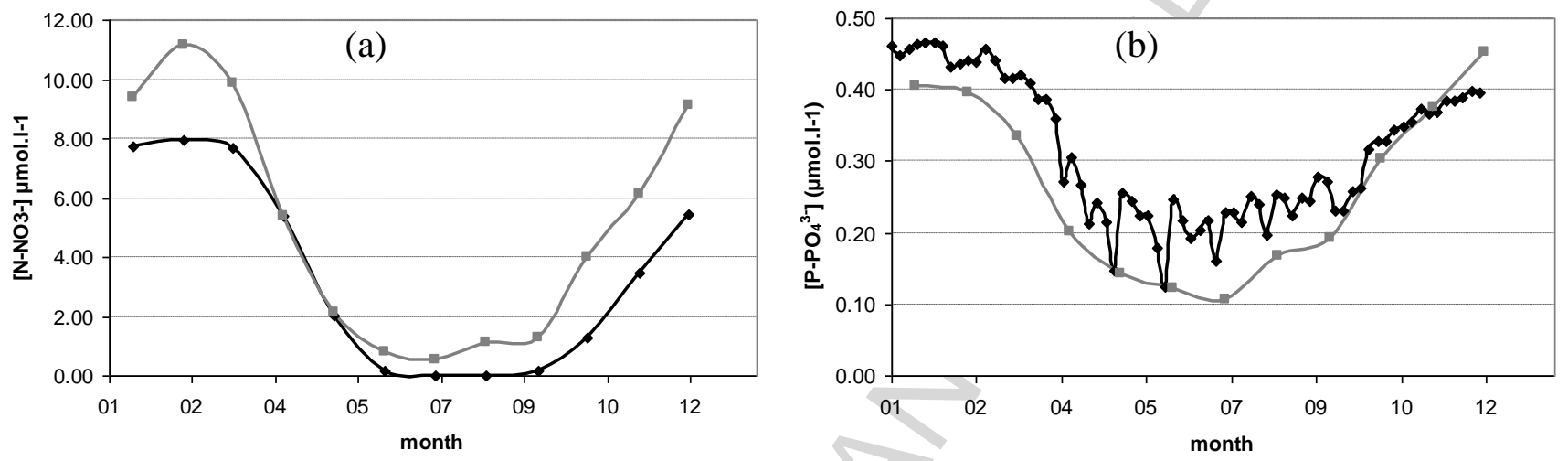
Figure 4: Simulated nitrate concentrations $\left(\mu\right.$ mol. $1^{-1}$ ) in (a) La Fresnaye Bay $(23 / 08 / 2004)$, (b)

Saint-Brieuc Bay (17/05/2002), (c) Lannion Bay (15/06/2005), (d) Guissény Bay (19/05/2005), and (e) Douarnenez Bay (17/06/2005).
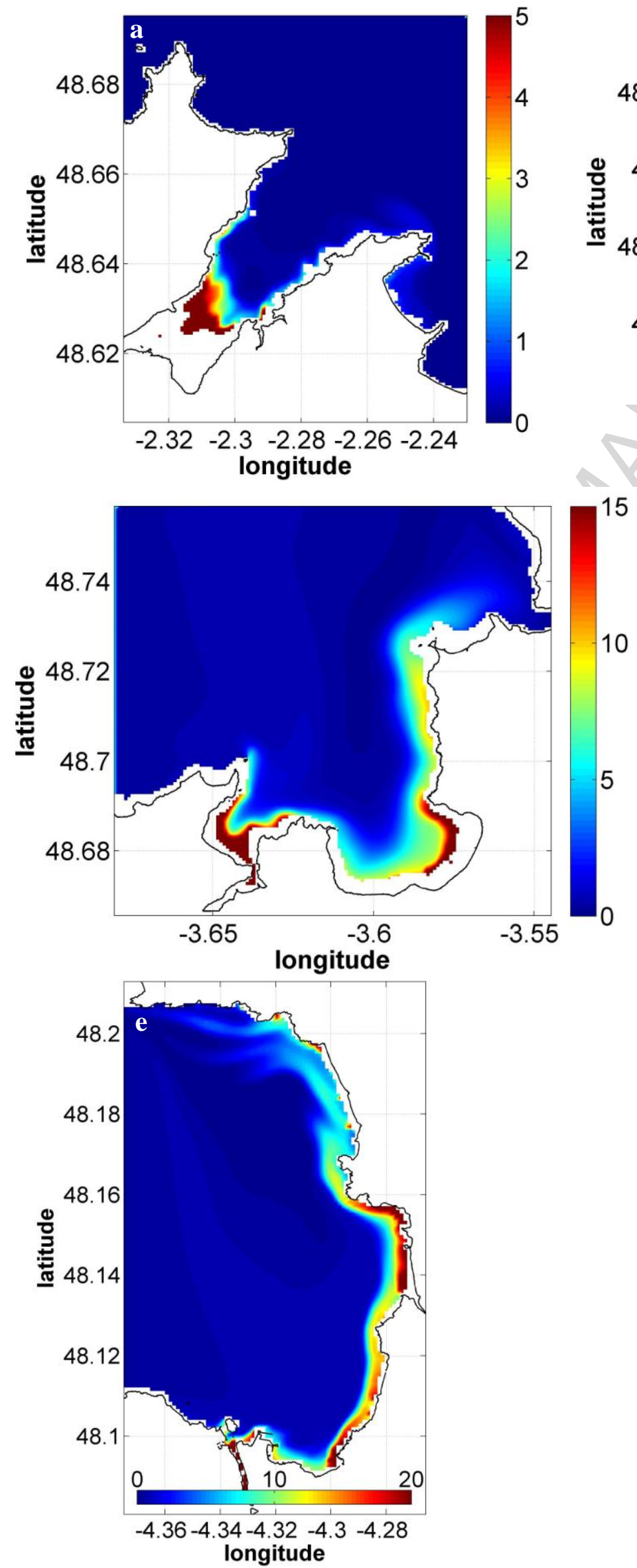
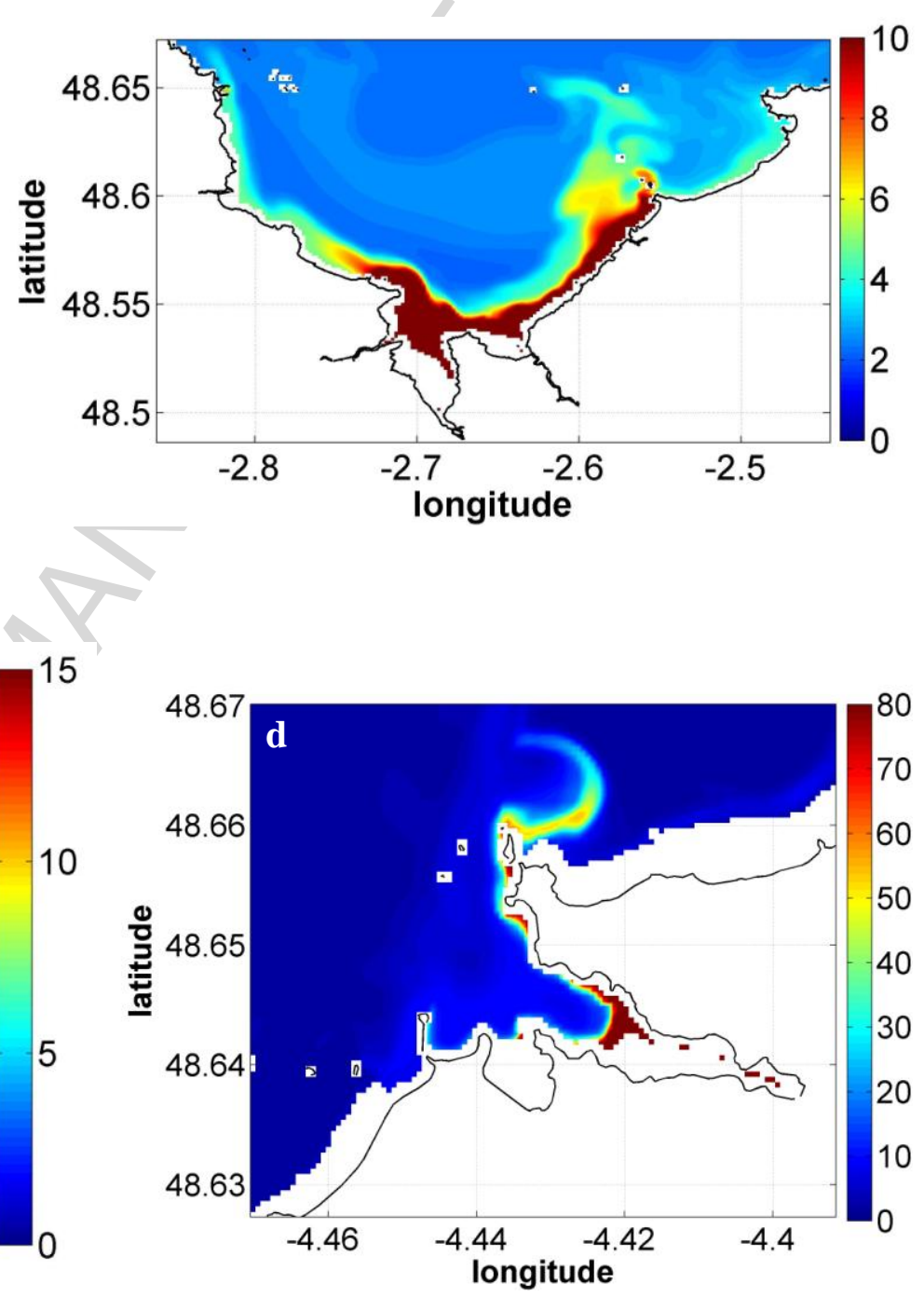
Figure 5: Changes in the light limitation factor according to solar radiation at the sea surface $\left(\mathrm{Wm}^{-2}\right)$ and the water height $\mathrm{H}(\mathrm{m})$ with a light extinction coefficient of $0.3 \mathrm{~m}^{-1}$.

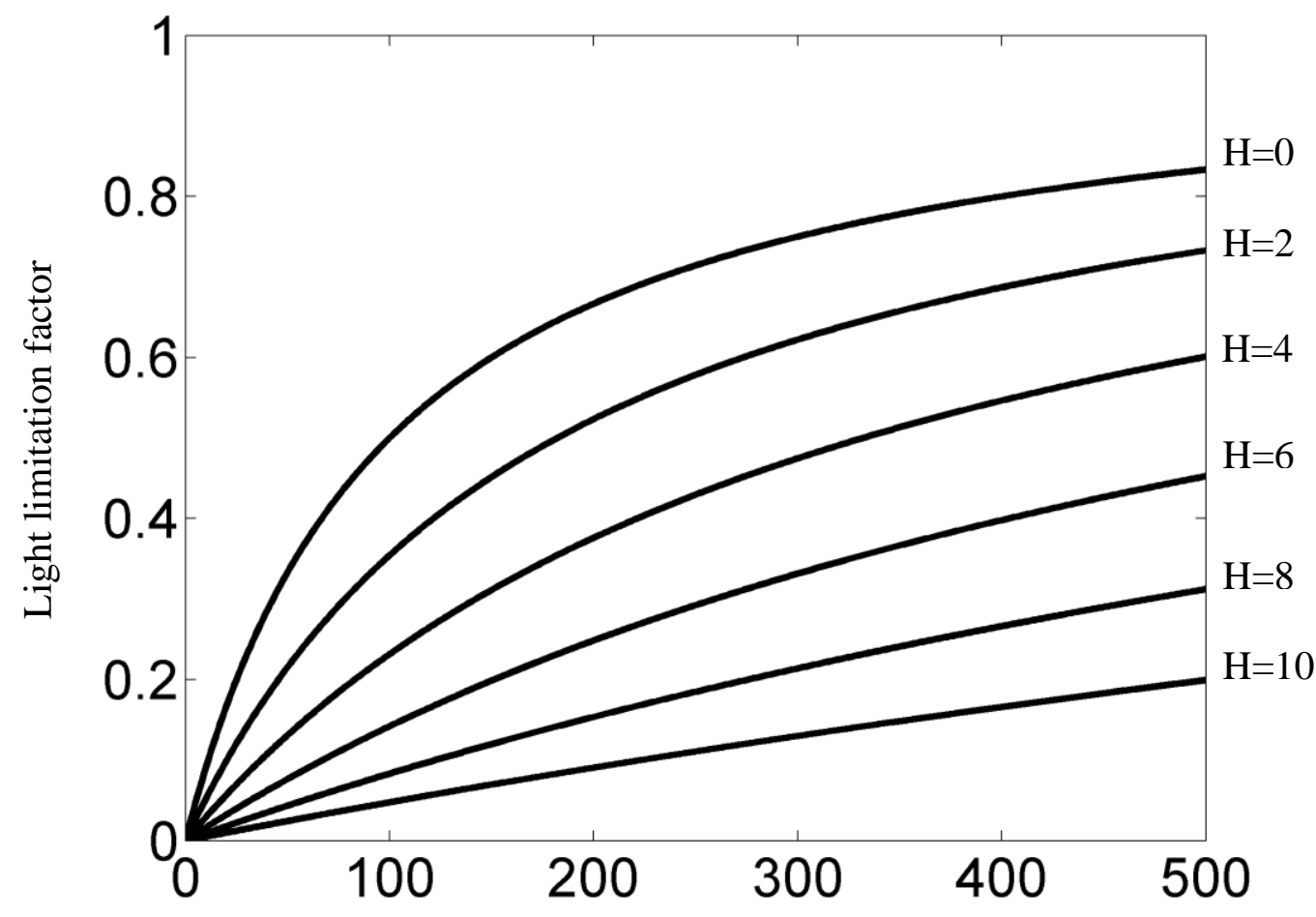

Solar radiation at the sea surface $\left(\mathrm{Wm}^{-2}\right)$ 
Figure 6: Physical and biological interactions between the components used in the coupled model MARS-Ulves.

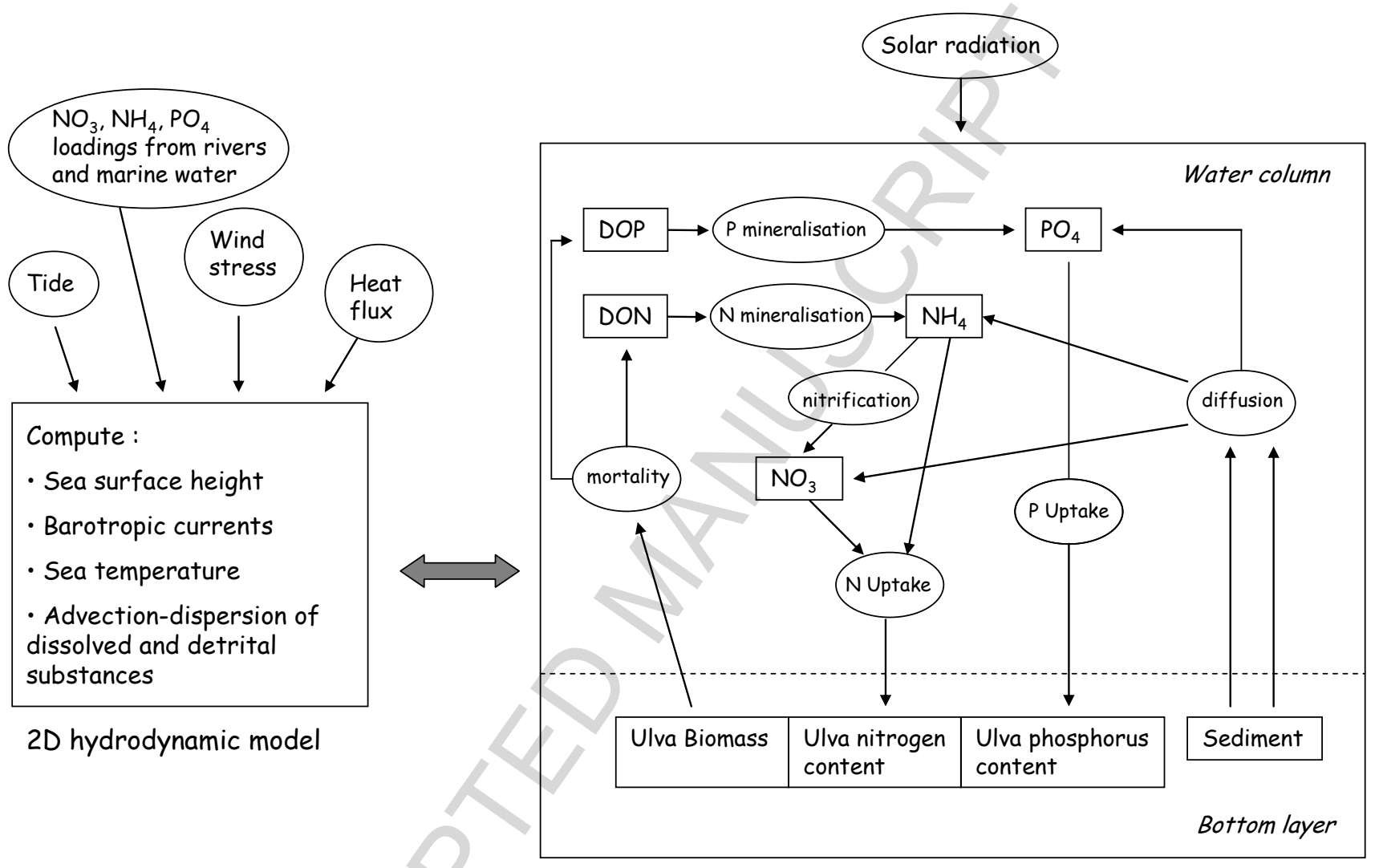

Ulva biological module 
Figure 7: Initial distribution of Ulva (green shading) derived from observed data in (a) La Fresnaye Bay, (b) Saint-Brieuc Bay, (c) Lannion Bay, (d) Guissény Bay and (e) Douarnenez Bay. Initial Ulva density was set to $20 \mathrm{~g} \mathrm{dw}$ in each site.
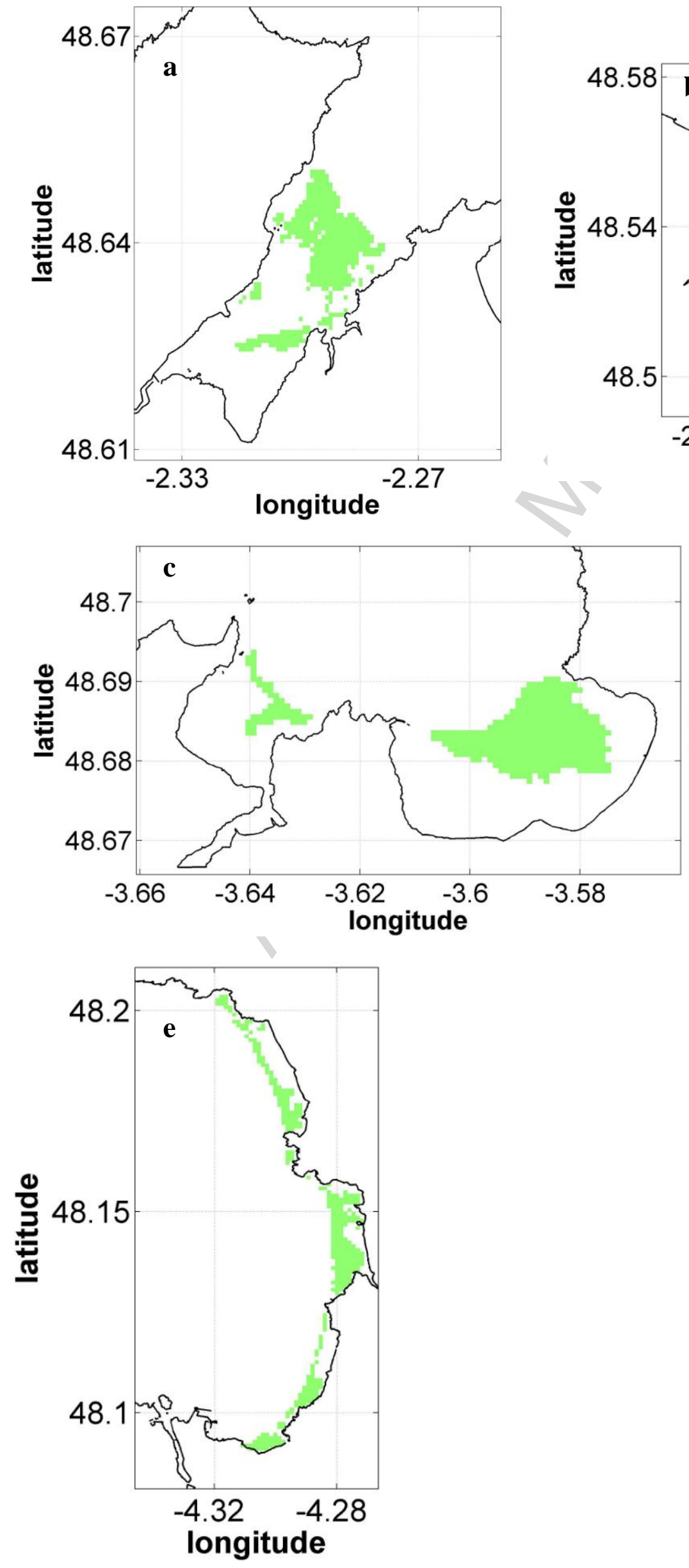
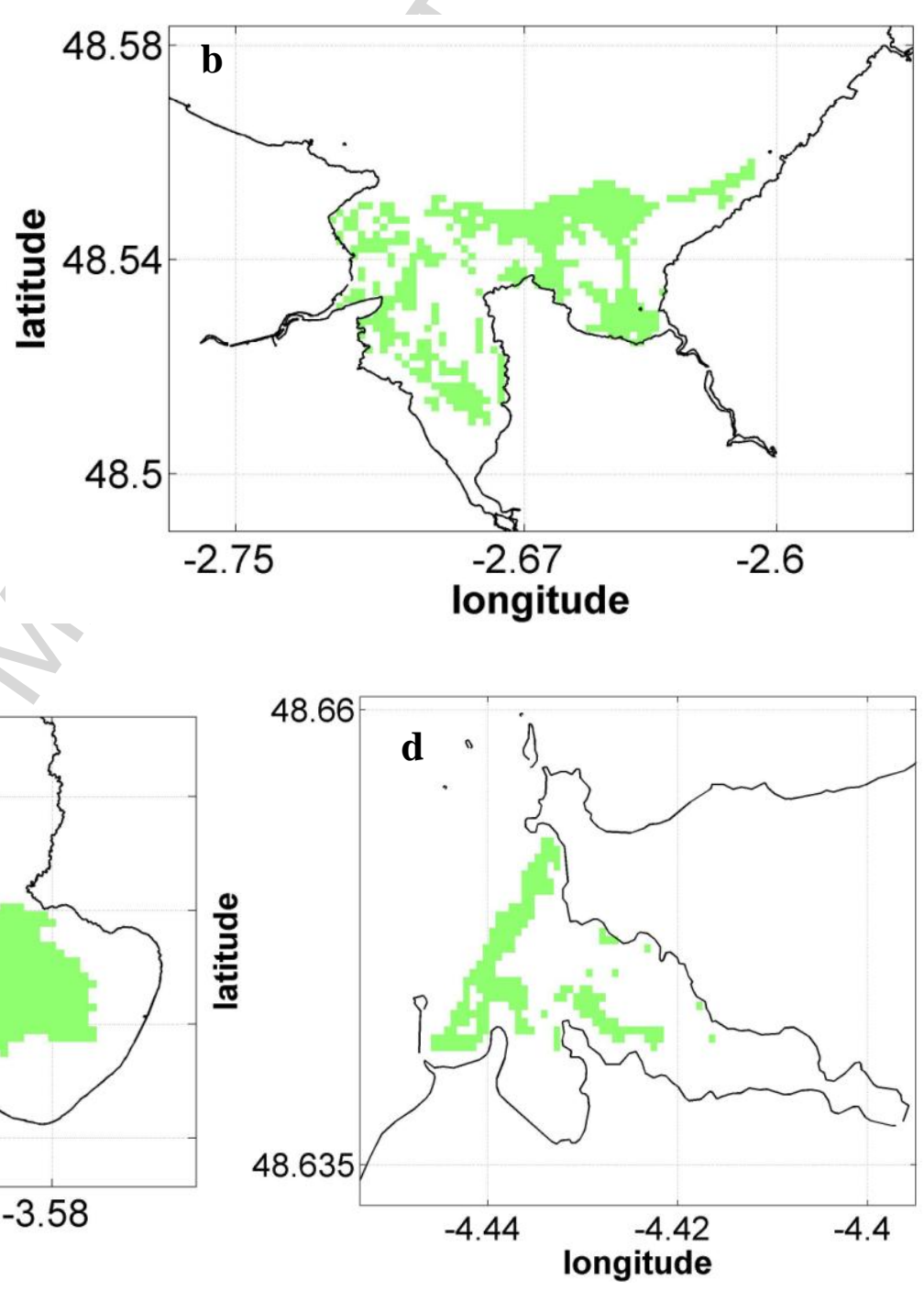
Figure 8: Seasonal changes in parameters for nitrate uptake $\left(\mathrm{V}_{\operatorname{maxN}}\right)$ and half-saturation constant $\left(\mathrm{K}_{\mathrm{N}}\right)$ after calibration of the model with measured internal nutrient quotas.
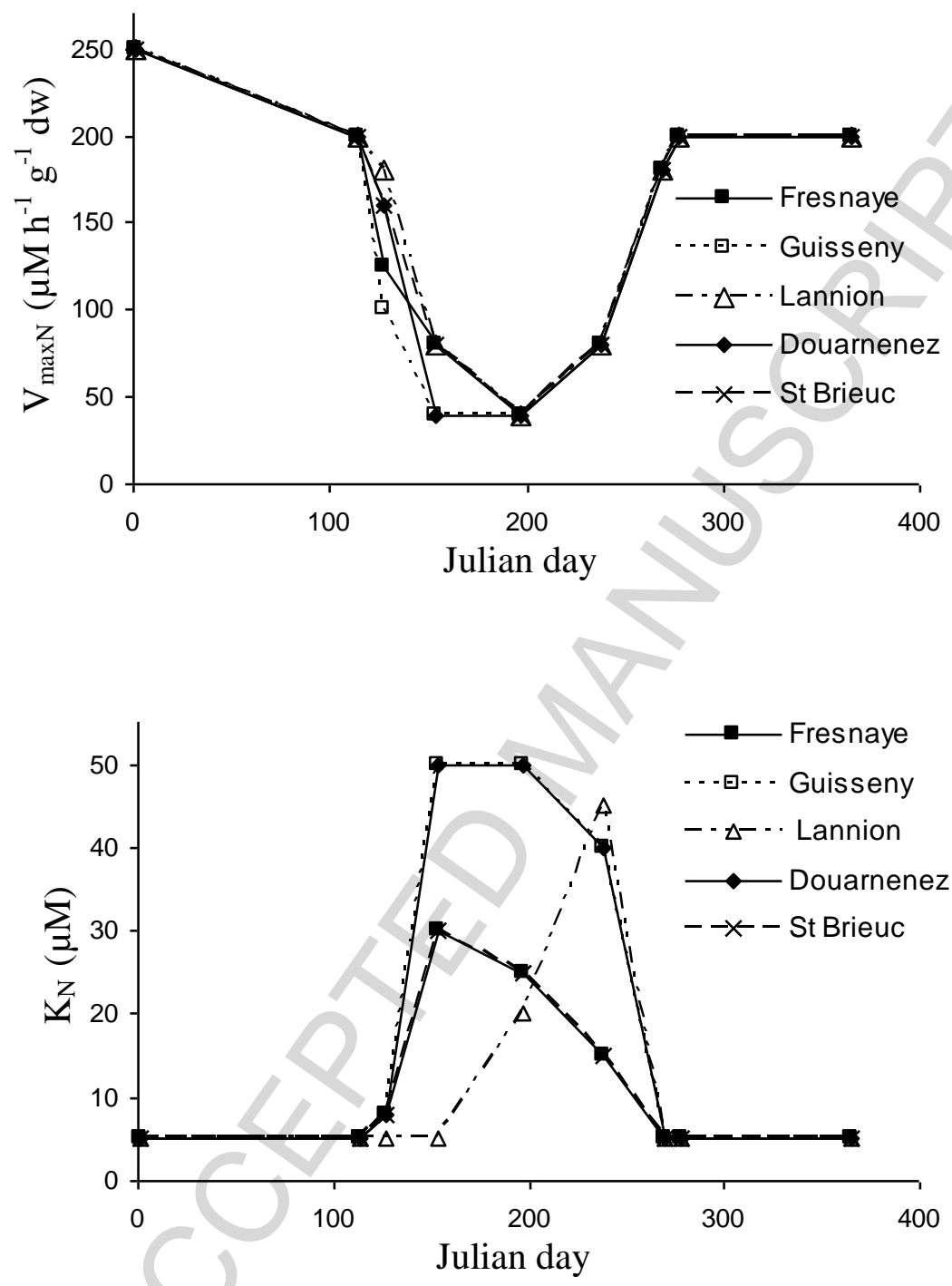
Figure 9: Changes in tidal height predicted by the Naval Hydrographic and Oceanographic Service (SHOM) and modelled for one point of the Lannion Bay site (a and b). Results are displayed according to the phase angle difference (c) and the relative error of the tidal range (d) to complete graphs a and b.
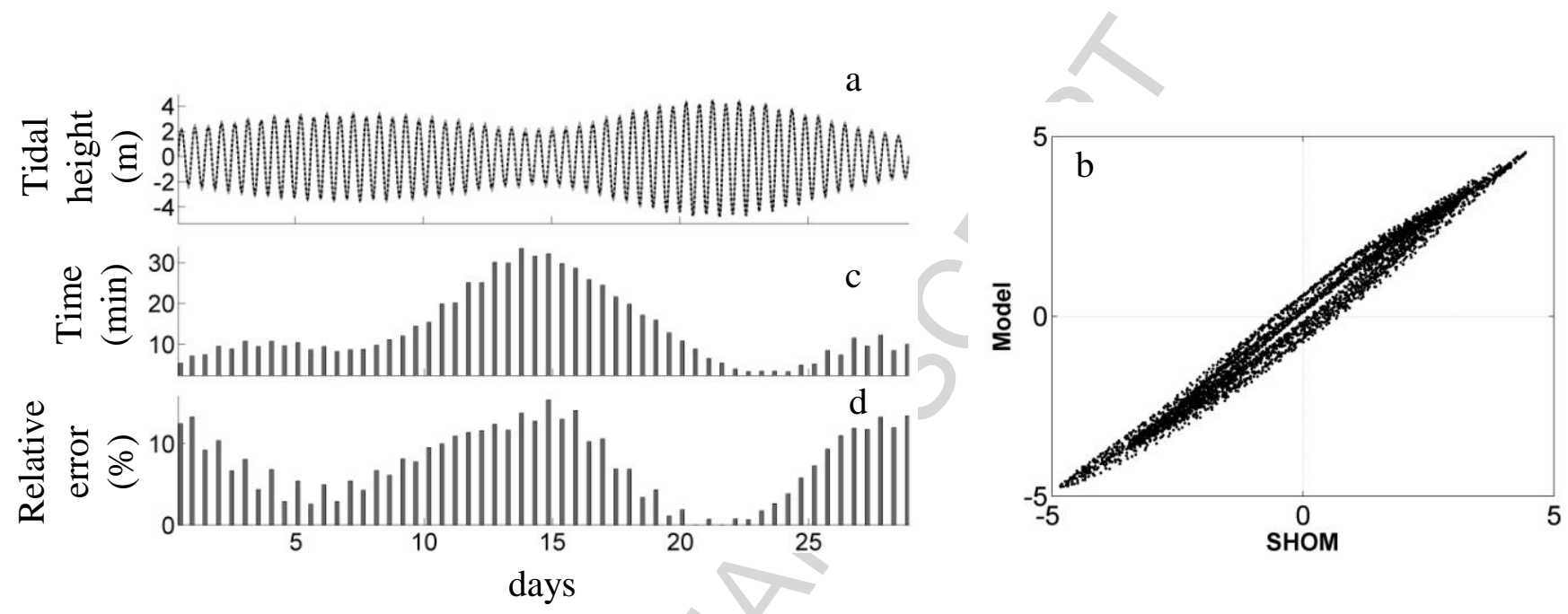
Figure 10: Results of biological validation (left-hand panels) and biological calibration (righthand panels). The biological validation is based on the qualitative comparison between the change in algal biomass modelled (black solid line) and measured in situ algal cover (line with + symbols). The calibration is based on the comparison between internal nitrogen content modelled (black solid line) and measured (line with + symbols). The solid black line gives the model results with a seasonal change in $\mathrm{V}_{\operatorname{maxN}}$ and $\mathrm{K}_{\mathrm{N}}$ for nitrate uptake in the model and the solid grey line shows the model results with constant $V_{\operatorname{maxN}}=200 \mu \mathrm{mol} \mathrm{g}^{-1} \mathrm{dw} \mathrm{h}^{-1}$ and $\mathrm{K}_{\mathrm{N}}=30 \mu \mathrm{mol} \mathrm{dm}{ }^{-3} \cdot \mathrm{R}^{2}$ is the coefficient of determination.

\section{Lannion}
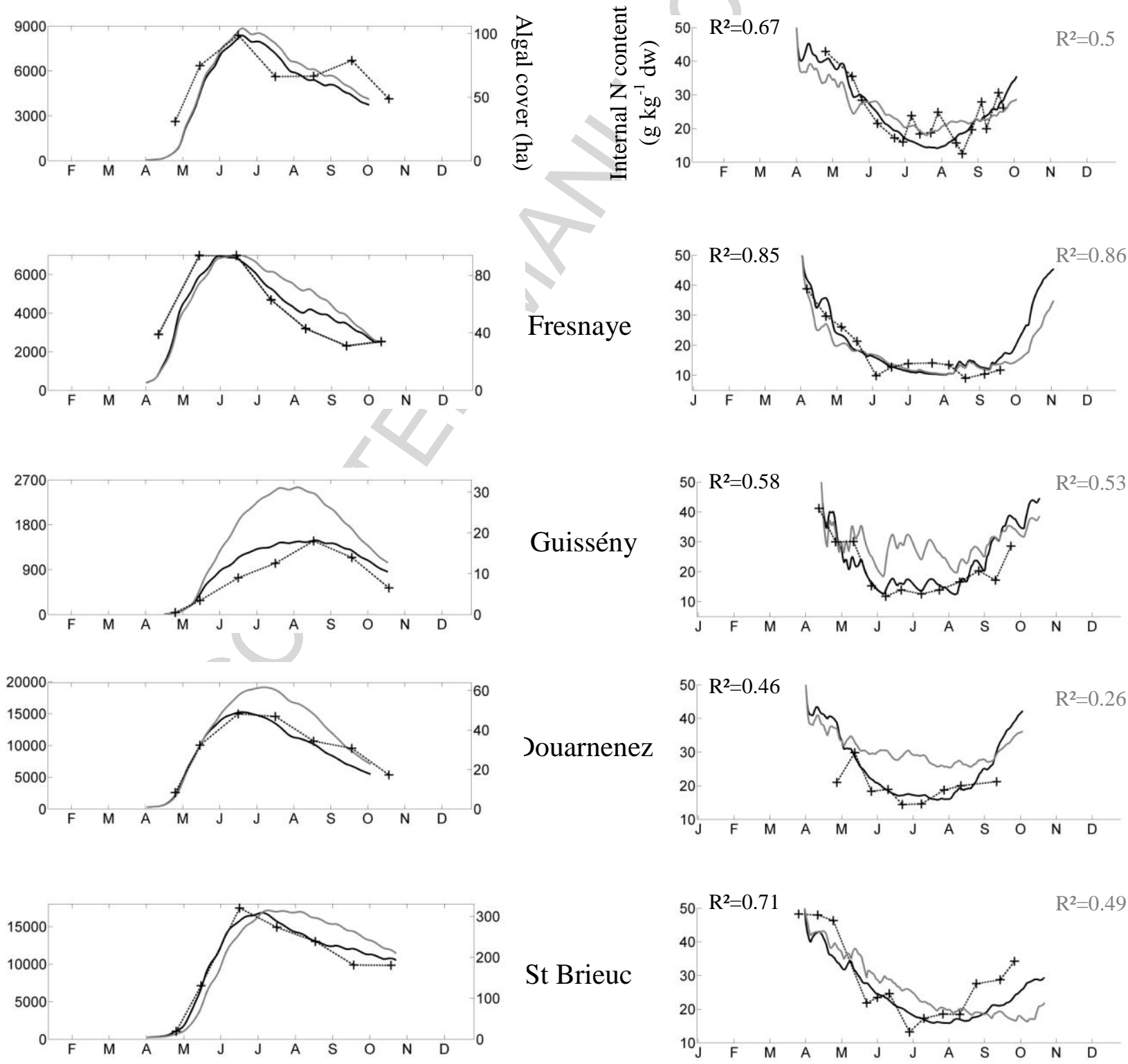
Figure 11: Relationship between measured Ulva cover and Ulva biomass provided by in situ data from all sites (white circles with fitted line) and for the model of each bay.

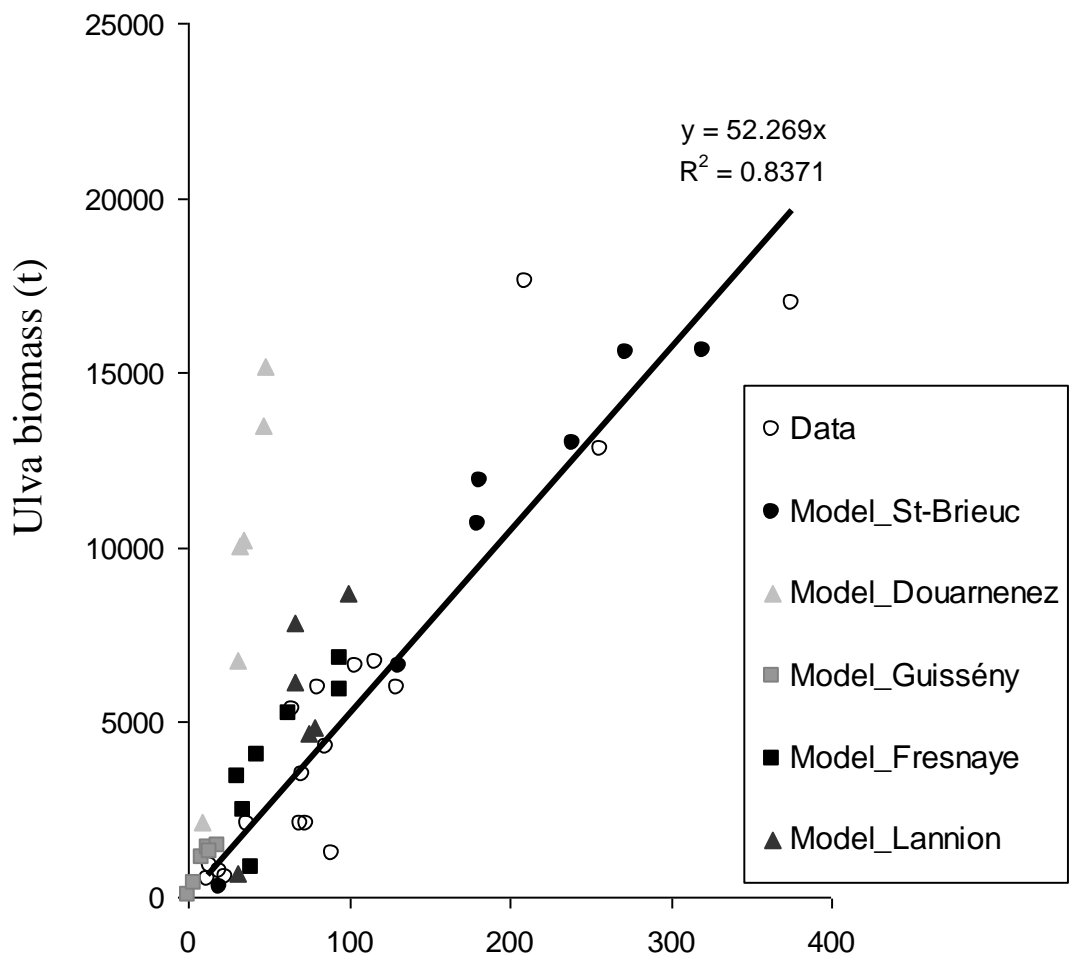

Ulva area (ha equivalent to $100 \%$ algal cover) 
Figure 12: Results for Lannion Bay for the one-way sensitivity analysis expressed as the mean relative deviation $(\%)$ between the baseline simulation and the simulation in which one variable was modified. Simulations were carried out on the period running from early April until late September across all spatial elements for biomass (a) and in three fixed points for the internal nitrogen quota (b). The sensitivity analysis consisted in varying $T_{\text {optmin }}$ and $T_{\text {optmax }}$ by $\pm 2{ }^{\circ} \mathrm{C}$ from their original values, by $\pm 20 \%$ for $V_{\max }, K_{N}, I_{\text {optulva }}, f_{T 2}^{0}$, ulvasurfo, $k_{\min N}^{0}, k_{\min P}^{0}, k_{n i t r i f}^{0}, m^{0}{ }_{\text {ulva }}$, $\mu_{\text {max ulva }}$, and by a factor of 0.5 and 2 for initial biomass (see variable abbreviations Table 3 )
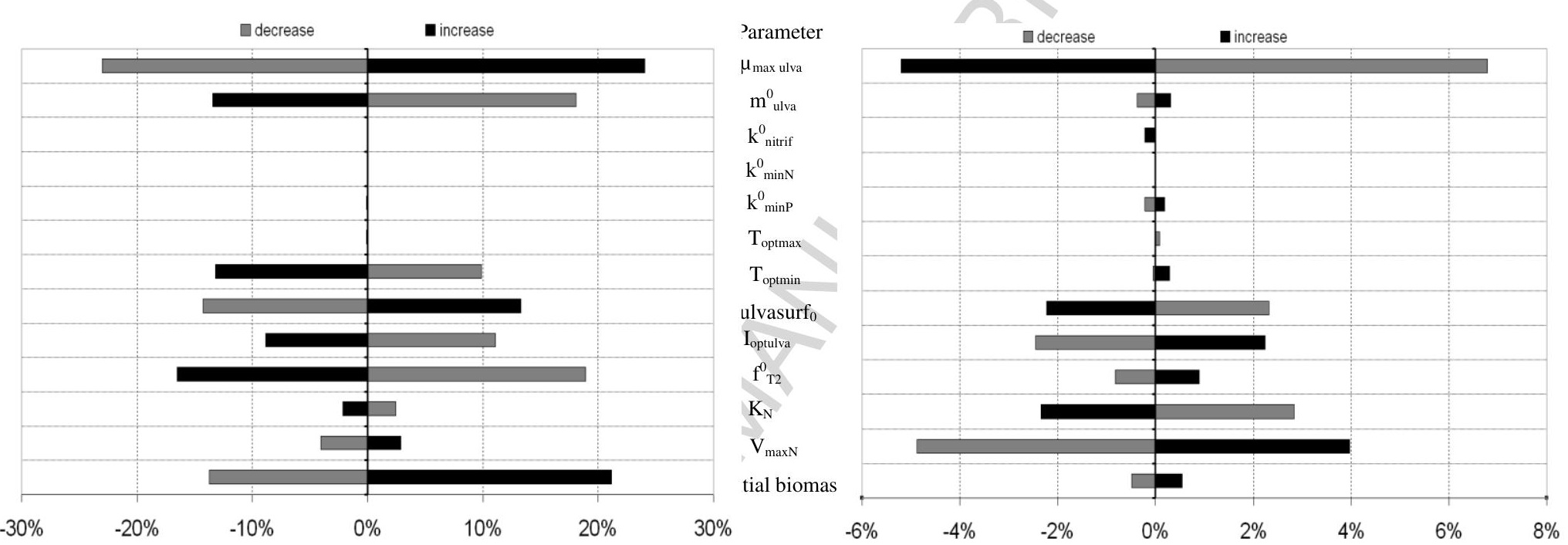

Mean relative deviation (\%) from the baseline simulation for each parameter 
Figure 13: Origin of nitrogen content in Ulva from the numerical tracking technique. The main rivers emptying into each bay are represented by letters. Lannion: (a) Yar, (b) Douron, (c) Roscoat, (d) natural open sea. Fresnaye: (e) Frémur, (f) natural open sea. Guissény: (g) Quillimadec, (h) Alanan, (i) natural open sea. Douarnenez: (j) Lapic, (k) natural open sea, (l) Port Rhu, (m) Kerharo, (n) Ris. Saint-Brieuc: (o) Gouet, (p) Gouessant, (q) Urne, (r) sediment, (s) natural open sea.
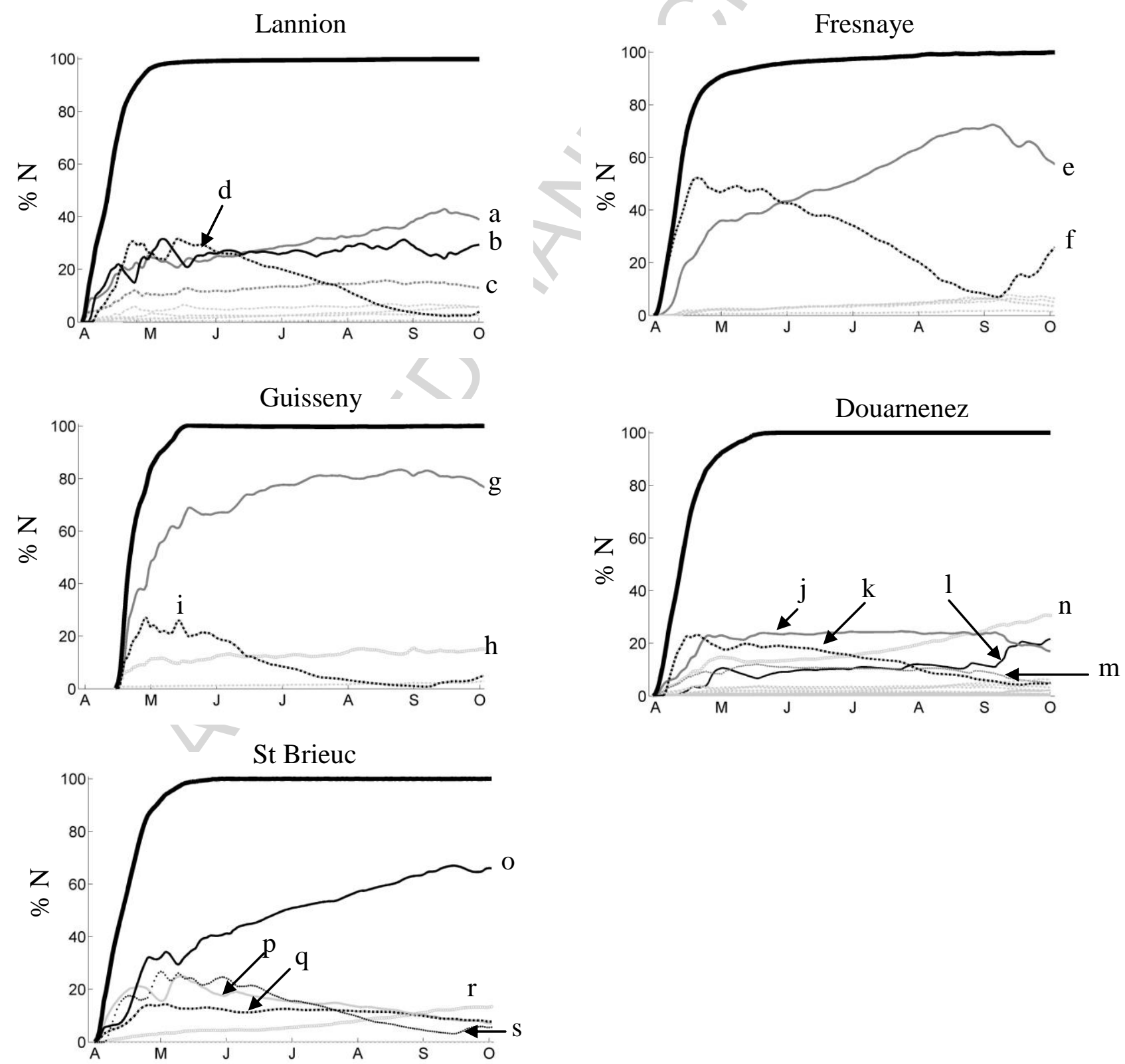
Figure 14: Nitrogen content in Ulva $\left(\mathrm{g} \mathrm{m}^{-2}\right)$ from different tributaries in Douarnenez Bay for the situation observed on 5 July 2005.
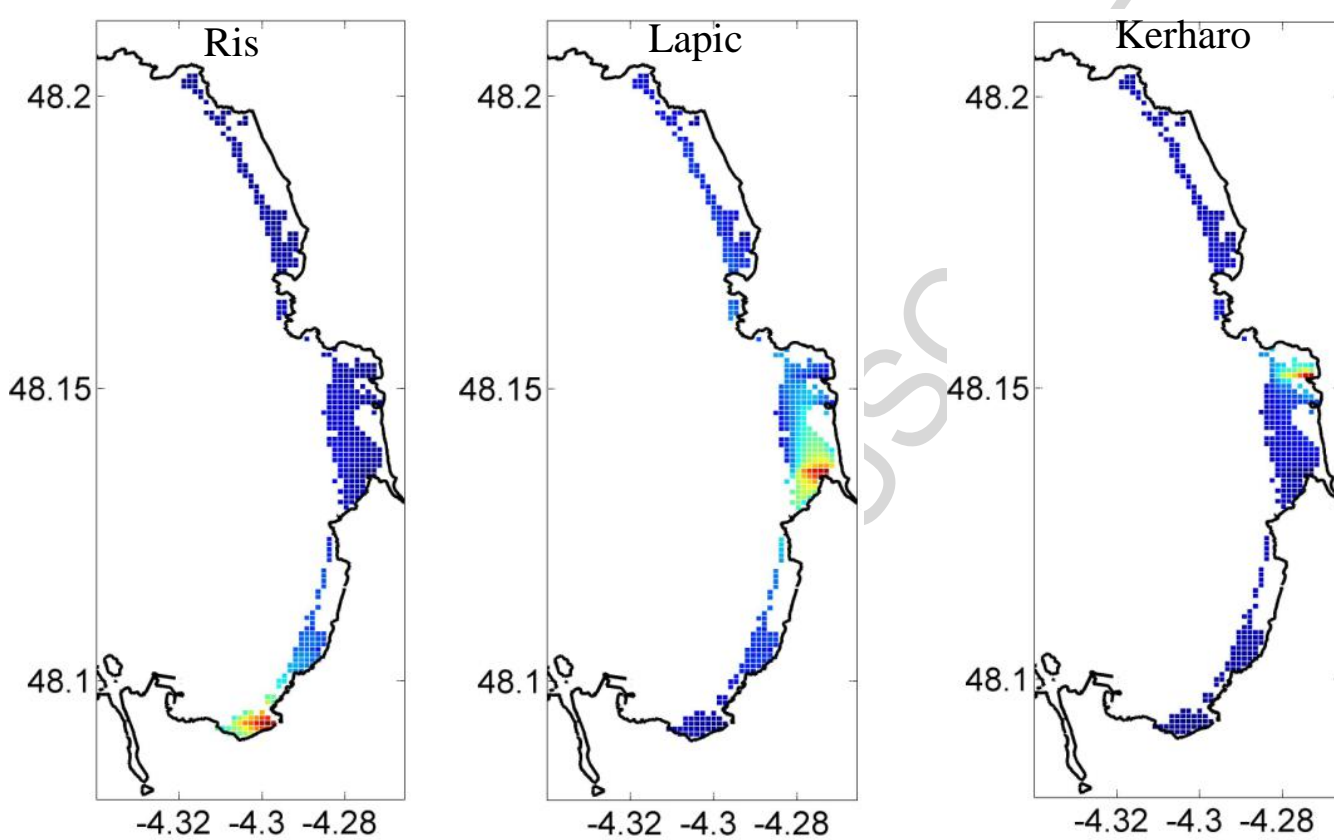

$\mathrm{N}\left(\mathrm{g} \mathrm{m}^{-2}\right)$
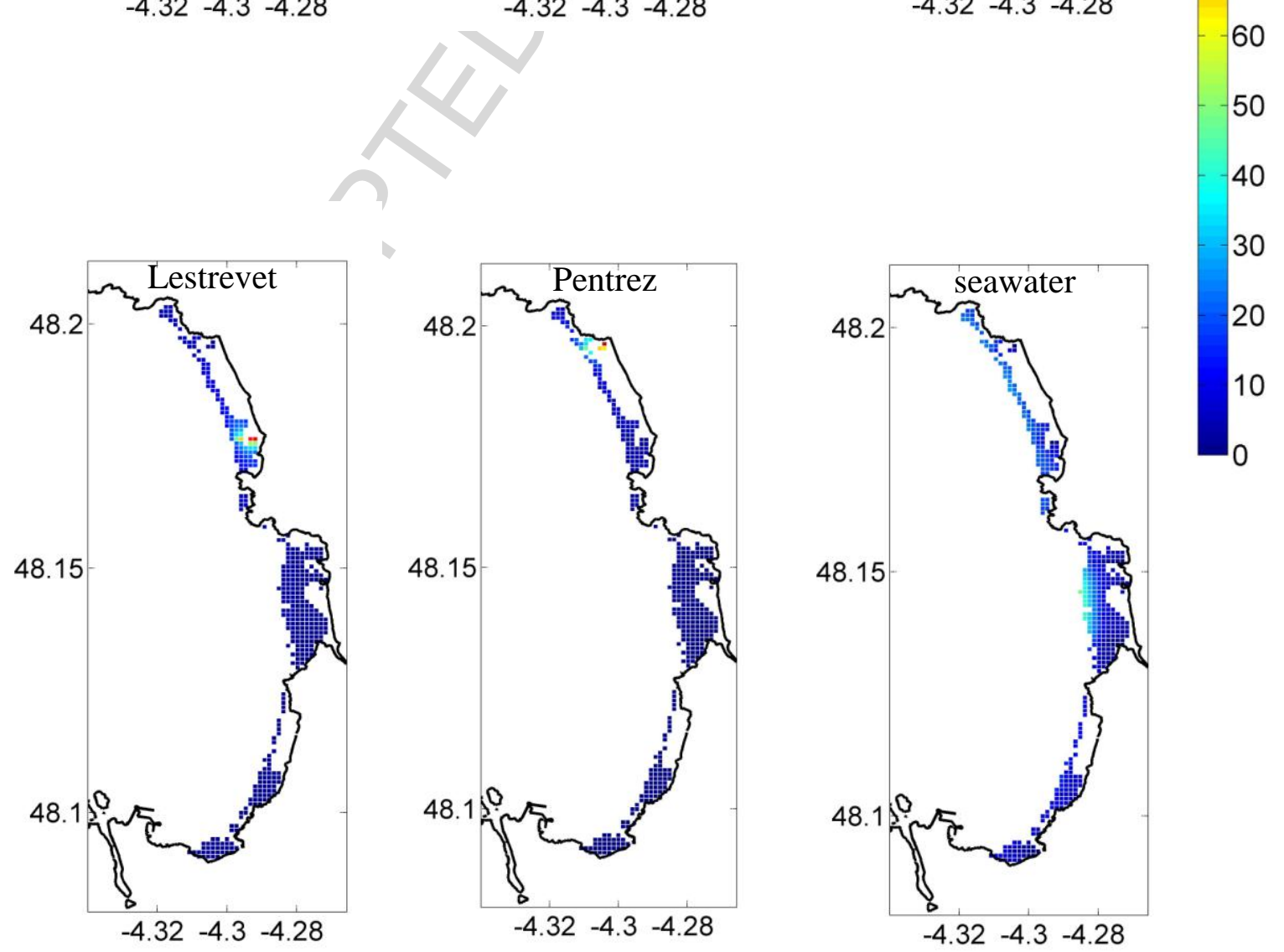
Table 1. Description of the study sites detailing their foreshore area and the changes in the maximum algal cover recorded from 2002 to 2009.

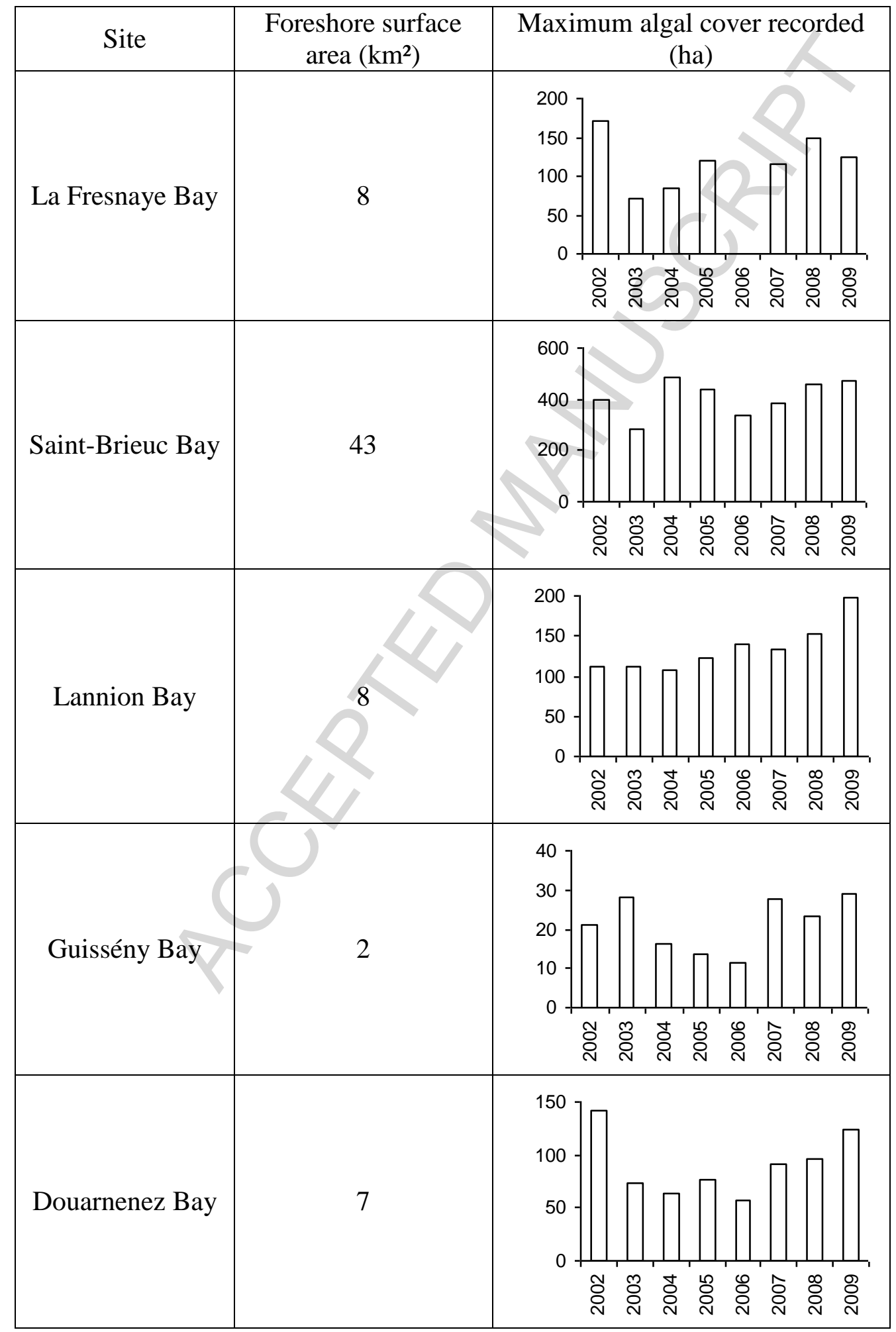


Table 2: State variables used in the MARS-Ulves model.

\begin{tabular}{ccc} 
Variable & Description & Unit \\
\hline 1 & nitrate & $\mu$ mol $\mathrm{dm}^{-3}$ \\
$X 2$ & ammonium & $\mu \mathrm{mol} \mathrm{N} \mathrm{dm}^{-3}$ \\
$X 3$ & phosphate & $\mu \mathrm{mol} \mathrm{P} \mathrm{dm}^{-3}$ \\
$X 4$ & detrital organic nitrogen & $\mu \mathrm{mol} \mathrm{N} \mathrm{dm}^{-3}$ \\
$X 5$ & detrital organic phosphorus & $\mu \mathrm{mol} \mathrm{P} \mathrm{dm}^{-3}$ \\
$X 6$ & nitrogen content of deposited $U l v a$ & $\mathrm{~g} \mathrm{~N} \mathrm{~m}^{-2}$ \\
$X 7$ & phosphorus content of deposited $U l v a$ & $\mathrm{~g} \mathrm{P} \mathrm{m}^{-2}$ \\
$X 8$ & biomass of settled Ulva & $\mathrm{kg} \mathrm{dw} \mathrm{m}^{-2}$
\end{tabular}


Table 3: Values of the variables used in the MARS-Ulves model.

\begin{tabular}{|c|c|c|c|}
\hline & Symbol & Unit & Value \\
\hline Maximal growth & $\mu_{\max \text { ulva }}$ & $d^{-1}$ & 0.8 \\
\hline Optimal light intensity & $\mathrm{I}_{\text {optulva }}$ & $\mathrm{W} \mathrm{m} \mathrm{m}^{-2}$ & 50 \\
\hline Light extinction coefficient & $\mathrm{k}_{\mathrm{z}}$ & $\mathrm{m}^{-1}$ & 0.3 \\
\hline $\begin{array}{l}\text { Effect of temperature on the kinetics of mortality, } \\
\text { mineralisation and nitrification }\end{array}$ & $f_{T_{2}}^{0}$ & & 0.07 \\
\hline Minimal temperature for the optimal growth interval & & ${ }^{\circ} \mathrm{C}$ & 15 \\
\hline Maximal temperature for the optimal growth interval & & ${ }^{\circ} \mathrm{C}$ & 23 \\
\hline Minimal tolerable temperature & & ${ }^{\circ} \mathrm{C}$ & 8 \\
\hline Maximal tolerable temperature & & ${ }^{\circ} \mathrm{C}$ & 28 \\
\hline Constant to control temperature response curve shape & $\mathrm{K}_{1}$ & dimensionless & 0.01 \\
\hline Constant to control temperature response curv & $\mathrm{K}_{2}$ & dimensionless & 0.999 \\
\hline Constant to control temperature response curve shape & $\mathrm{K}_{3}$ & dimensionless & 0.98 \\
\hline Constant to control temperature response curve shape & $\mathrm{K}_{4}$ & dimensionless & 0.02 \\
\hline Nitrogen half-saturation constant & $\mathrm{K}_{\mathrm{N}}$ & $\mu \mathrm{mol} \mathrm{dm}{ }^{-3}$ & $5-50$ \\
\hline Phosphorus half-saturation constant & $\mathrm{K}_{\mathrm{P}}$ & $\mu \mathrm{mol} \mathrm{dm}{ }^{-3}$ & $0.9-5.8$ \\
\hline Maximum nitrogen uptake rate & $\mathrm{V}_{\operatorname{maxN}}$ & $\mu \mathrm{mol} \mathrm{g}{ }^{-1} \mathrm{dw} \mathrm{h}$ & $40-200$ \\
\hline Maximum phosphorus uptake rate & $\mathrm{V}_{\max P}$ & $\mu \mathrm{mol} \mathrm{g}{ }^{-1} \mathrm{dw} \mathrm{h}$ & $8.8-35.2$ \\
\hline Maximum nitrogen:dry weight ratio & $\mathrm{Q}_{\operatorname{maxN}}$ & $\mathrm{mg} \mathrm{g}^{-1}$ & 50 \\
\hline Minimum nitrogen:dry weight ratio & $\mathrm{Q}_{\min N}$ & $\operatorname{mg~g~}^{-1}$ & 10 \\
\hline Maximum phosphorus:dry weight ratio & $\mathrm{Q}_{\max P}$ & $\mathrm{mg} \mathrm{g}^{-1}$ & 4 \\
\hline Minimum phosphorus:dry weight ratio & $\mathrm{Q}_{\min P}$ & $\mathrm{mg} \mathrm{g}^{-1}$ & 1 \\
\hline Mortality rate at $0^{\circ} \mathrm{C}$ & $m_{u l v a}^{0}$ & $d^{-1}$ & 0.02 \\
\hline Specific biomass self-shading parameter & ulvasurf $_{0}$ & $\mathrm{~g} \mathrm{dw} \mathrm{m}^{-2}$ & 0.05 \\
\hline Ammonium sediment flux & $\mathrm{SED}_{\mathrm{NH} 4}$ & $\mu \mathrm{mol} \mathrm{m} \mathrm{d}^{-2}$ & 500 \\
\hline Nitrate sediment flux & $\mathrm{SED}_{\mathrm{NO} 3}$ & $\mu \mathrm{mol} \mathrm{m} \mathrm{d}^{-1}$ & 560 \\
\hline Dissolved phosphorus sediment flux & $\mathrm{SED}_{\mathrm{PO} 4}$ & $\mu \mathrm{mol} \mathrm{m} \mathrm{d}^{-1}$ & 350 \\
\hline Nitrogen mineralisation rate at $0^{\circ} \mathrm{C}$ & $k_{\min N}^{0}$ & $d^{-1}$ & 0.01 \\
\hline Nitrification rate at $0^{\circ} \mathrm{C}$ & $k_{\text {nitrif }}^{0}$ & $\mathrm{~d}^{-1}$ & 0.2 \\
\hline Phosphorus mineralisation rate at $0^{\circ} \mathrm{C}$ & $k_{\min P}^{0}$ & $d^{-1}$ & 0.1 \\
\hline
\end{tabular}


Table 4: Relative error between tide predicted by SHOM and tide modelled considering the phase angle difference $(\Delta t)$ and the tidal range $(\Delta \mathrm{M})$.

\begin{tabular}{|c|c|c|}
\cline { 2 - 3 } \multicolumn{1}{c|}{} & $\Delta \mathrm{t}(\min )$ & $\Delta \mathrm{M}(\%)$ \\
\hline Douarnenez & 9.6 & 14.9 \\
\hline Guisseny & 13.1 & 14.6 \\
\hline Lannion & 14.8 & 13.2 \\
\hline St Brieuc & 21.3 & 13.9 \\
\hline Fresnaye & 19 & 16 \\
\hline
\end{tabular}


Table 5: Nitrate concentrations $\left(\mathrm{NO}_{3}{ }^{-}\right)$and total dissolved inorganic nitrogen (NID) fluxes from May to September in the main rivers of each bay. Data taken from in situ data sets which are related to the year modelled (2002 for Saint-Brieuc, 2004 for La Fresnaye and 2005 for Lannion, Douarnenez, Guissény).

\begin{tabular}{|l|c|c|c|c|}
\hline FRESNAYE & Fremur & Rat & Clos & Kermiton \\
\hline $\mathrm{NO}_{3}{ }^{-}\left(\mathrm{mg} \mathrm{l}^{-1}\right)$ & 50.1 & 25.8 & 39.9 & 52.5 \\
\hline $\mathrm{NID}\left(\mathrm{kg} \mathrm{day}^{-1}\right)$ & 170 & 16 & 21 & 10 \\
\hline
\end{tabular}

\begin{tabular}{|l|c|c|}
\hline GUISSENY & Quillimadec & Alanan \\
\hline $\mathrm{NO}_{3}{ }^{-}\left(\mathrm{mg} \mathrm{l}^{-1}\right)$ & 58.3 & 37.3 \\
\hline $\mathrm{NID}\left(\mathrm{kg} \mathrm{day}^{-1}\right)$ & 503 & 61 \\
\hline
\end{tabular}

\begin{tabular}{|l|c|c|c|c|}
\hline DOUARNENEZ & Port Rhu & Ris & Lapic & Kerharo \\
\hline $\mathrm{NO}_{3}{ }^{-}\left(\mathrm{mg} \mathrm{l}^{-1}\right)$ & 42.5 & 41.7 & 36.7 & 26.4 \\
\hline $\mathrm{NID}\left(\mathrm{kg} \mathrm{day}^{-1}\right)$ & 40 & 14 & 8 & 7 \\
\hline
\end{tabular}

\begin{tabular}{|l|c|c|c|}
\hline LANNION & Yar & Douron & Roscoat \\
\hline $\mathrm{NO}_{3}{ }^{-}\left(\mathrm{mg} \mathrm{l}^{-1}\right)$ & 32.1 & 35.0 & 33.3 \\
\hline $\left.\mathrm{NID}^{-1} \mathrm{~kg} \mathrm{day}^{-1}\right)$ & 28 & 58 & 11 \\
\hline
\end{tabular}

\begin{tabular}{|l|c|c|}
\hline SAINT-BRIEUC & Gouet & Gouessant \\
\hline $\mathrm{NO}_{3}^{-}\left(\mathrm{mg} \mathrm{l}^{-1}\right)$ & 24.0 & 20.3 \\
\hline $\mathrm{NID}\left(\mathrm{kg} \mathrm{day}^{-1}\right)$ & 657 & 213 \\
\hline
\end{tabular}


Table 6: Results of the different nitrogen reduction scenarios. All tributaries of each bay were successively set to 5, 10, 15, 20, 25 and $30 \mathrm{mg} \mathrm{l}^{-1}$ (except for Saint-Brieuc). Values are the percentage of the algal biomass reduction for the August-September period.

\begin{tabular}{|l|c|c|c|c|c|}
\cline { 2 - 5 } \multicolumn{1}{c|}{} & $\begin{array}{c}\text { Lannion } \\
2005\end{array}$ & $\begin{array}{c}\text { Douarnenez } \\
2005\end{array}$ & $\begin{array}{c}\text { Saint-Brieuc } \\
2002\end{array}$ & $\begin{array}{c}\text { Guissény } \\
2005\end{array}$ & $\begin{array}{c}\text { Fresnaye } \\
2004\end{array}$ \\
\hline $5 \mathrm{mg} \mathrm{l}^{-1}$ & 69 & 77 & 54 & 71 & 74 \\
\hline $10 \mathrm{mg} \mathrm{l}^{-1}$ & 51 & 60 & 41 & 53 & 62 \\
\hline $15 \mathrm{mg} \mathrm{l}^{-1}$ & 36 & 44 & 30 & 41 & 51 \\
\hline $20 \mathrm{mg} \mathrm{l}^{-1}$ & 23 & 29 & & 31 & 42 \\
\hline $25 \mathrm{mg} \mathrm{l}^{-1}$ & 13 & 15 & & 25 & 31 \\
\hline $30 \mathrm{mg} \mathrm{l}^{-1}$ & 6 & 8 & & 18 & 24 \\
\cline { 5 - 6 } & & & & & \\
\cline { 5 - 6 } & & & & &
\end{tabular}

